NUREG/CR-6363

ORNL/TM-13047

\title{
Effects of Thermal Aging and \\ Neutron Irradiation on the \\ Mechanical Properties of \\ Three-Wire Stainless Steel Weld \\ Overlay Cladding
}

Manuscript Completed: April 1995

Date Published: May 1997

Prepared by

F. M. Haggag, R. K. Nanstad

Oak Ridge National Laboratory

Managed by Lockheed Martin Energy Research Corporation

Oak Ridge National Laboratory

Oak Ridge, TN 37831

M. Vassilaros, NRC Project Manager

Prepared for

Division of Engineering Technology

Office of Nuclear Regulatory Research

U.S. Nuclear Regulatory Commission

Washington, DC 20555-0001

NRC Job Code L1098 


\begin{abstract}
Thermal aging of three-wire series-arc stainless steel weld overlay cladding at $288^{\circ} \mathrm{C}$ for $1605 \mathrm{~h}$ resulted in an appreciable decrease (16\%) in the Charpy V-notch (CVN) upper-shelf energy (USE), but the effect on the 41-J transition temperature shift was very small $\left(3^{\circ} \mathrm{C}\right)$. The combined effect of aging and neutron irradiation at $288^{\circ} \mathrm{C}$ to a fluence of $5 \times 10^{19}$ neutrons $/ \mathrm{cm}^{2}\left(>1 \mathrm{MeV}\right.$ ) was a $22 \%$ reduction in the USE and a $29^{\circ} \mathrm{C}$ shift in the $41-\mathrm{J}$ transition temperature. The effect of thermal aging on tensile properties was very small. However, the combined effect of irradiation and aging was an increase in the yield strength ( 6 to $34 \%$ at test temperatures from 288 to $-125^{\circ} \mathrm{C}$ ) but no apparent change in ultimate tensile strength or total elongation. Neutron irradiation reduced the initiation fracture toughness $\left(\mathrm{J}_{\mathrm{l}}\right)$ much more than did thermal aging alone. Irradiation slightly decreased the tearing modulus, but no reduction was caused by thermal aging alone. Other results from tensile, $\mathrm{CVN}$, and fracture toughness specimens showed that the effects of thermal aging at 288 or $343^{\circ} \mathrm{C}$ for $20,000 \mathrm{~h}$ each were very small and similar to those at $288^{\circ} \mathrm{C}$ for $1605 \mathrm{~h}$. The effects of long-term thermal exposure time $\left(50,000 \mathrm{~h}\right.$ and greater) at $288^{\circ} \mathrm{C}$ will be investigated as the specimens become available in 1996 and beyond.
\end{abstract}




\section{DISCLAMMIER}

Portions of this document may be illegible in electronic image products. Images are produced from the best available original document. 


\section{Figures}

Page

1 Effects of thermal aging at $288^{\circ} \mathrm{C}$ and neutron irradiation on the Charpy impact energy

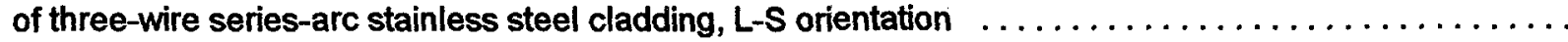

2 Effects of thermal aging at $288^{\circ} \mathrm{C}$ and neutron irradiation on the Charpy impact lateral expansion of three-wire series-arc stainless steel cladding, $L-S$ orientation $\ldots \ldots \ldots \ldots \ldots \ldots \ldots \ldots$

3 Effects of thermal aging at $288^{\circ} \mathrm{C}$ and neutron irradiation on the yield strength of three-wire series-arc stainless steel cladding

4 Effects of thermal aging at $288^{\circ} \mathrm{C}$ and neutron irradiation on the ultimate strength of three-wire series-arc stainless steel cladding

5 Effects of thermal aging at $288^{\circ} \mathrm{C}$ and neutron irradiation on the total elongation of three-wire series-arc stainless steel cladding

6 Effects of neutron irradiation and thermal aging at $288^{\circ} \mathrm{C}$ on the initiation fracture toughness, $J_{\mathrm{Ic}}$, of three-wire stainless steel cladding at various test temperatures

7 Effects of neutron irradiation and thermal aging at $288^{\circ} \mathrm{C}$ on the deformation J-integral tearing modulus of three-wire stainless steel cladding at various test temperatures

8 Effect of thermal aging at $288^{\circ} \mathrm{C}$ for $20,000 \mathrm{~h}$ on the Charpy impact energy of three-wire series-arc stainless steel cladding, L-S orientation

9 Effect of thermal aging at $288^{\circ} \mathrm{C}$ for $20,000 \mathrm{~h}$ on the Charpy impact lateral expansion of three-wire series-arc stainless steel cladding, L-S orientation

10 Effect of thermal aging at $343^{\circ} \mathrm{C}$ for $20,000 \mathrm{~h}$ on the Charpy impact energy of three-wire

series-arc stainless steel cladding, L-S orientation

11 Effect of thermal aging at $343^{\circ} \mathrm{C}$ for $20,000 \mathrm{~h}$ on the Charpy impact lateral expansion of three-wire series-arc stainless steel cladding, L-S orientation

12 Comparison of the effects of thermal aging at 288 or $343^{\circ} \mathrm{C}$ for $20,000 \mathrm{~h}$ on the Charpy impact energy of three-wire series-arc stainless steel cladding, L-S orientation $\ldots \ldots \ldots \ldots \ldots \ldots$

13 Comparison of the effects of thermal aging at 288 or $343^{\circ} \mathrm{C}$ for $20,000 \mathrm{~h}$ on the Charpy impact lateral expansion of three-wire series-arc stainless cladding, L-S orientation

14 Comparison of the effects of thermal aging at 288 or $343^{\circ} \mathrm{C}$ for $20,000 \mathrm{~h}$ on the yield strength of three-wire series-arc stainless steel cladding

15 Comparison of the effects of thermal aging at 288 or $343^{\circ} \mathrm{C}$ for $20,000 \mathrm{~h}$ on the ultimate strength of three-wire series-arc stainless steel cladding

16 Comparison of the effects of thermal aging at 288 or $343^{\circ} \mathrm{C}$ for $20,000 \mathrm{~h}$ on the total elongation of three-wire series-arc stainless steel cladding 


\section{Figures (continued)}

17 Effect of thermal aging at $288^{\circ} \mathrm{C}$ for 1605 or $20,000 \mathrm{~h}$ on the initiation fracture toughness $\left(\mathrm{J}_{\mathrm{I}}\right)$ of three-wire series-arc stainless steel cladding

18 Effect of thermal aging at $288^{\circ} \mathrm{C}$ for 1605 or $20,000 \mathrm{~h}$ on the tearing modulus of three-wire series-arc stainless steel cladding

19 Comparison of the effects of thermal aging at 288 or $343^{\circ} \mathrm{C}$ for $20,000 \mathrm{~h}$ on the initiation fracture toughness $\left(\mathrm{J}_{t e}\right)$ of three-wire series-arc stainless steel cladding

20 Comparison of the effects of thermal aging at 288 or $343^{\circ} \mathrm{C}$ for $20,000 \mathrm{~h}$ on the tearing modulus of three-wire series-arc stainless steel cladding

\section{Tables}

1 Chemical composition of the three-wire stainless steel weld clad overlay used in

Phase 2 of the Seventh Irradiation Series

2 Charpy impact test results for stainless steel three-wire series-arc cladding (L-S orientation)

3 Tensile properties of unirradiated specimens in the $L$ orientation

4 Tensile properties of thermally aged $\left(1605 \mathrm{~h}\right.$ at $\left.288^{\circ} \mathrm{C}\right)$ specimens in the $\mathrm{L}$ orientation

5 Tensile properties of irradiated specimens [at $288^{\circ} \mathrm{C}$ to $5 \times 10^{19}$ neutrons $/ \mathrm{cm}^{2}(>1 \mathrm{MeV})$ ]

in the $L$ orientation

6 Unloading compliance J-R test results of 12.7-mm-thick three-wire stainless steel cladding fracture toughness specimens ( $10 \%$ side-grooved on each side)

7 Charpy impact test results for stainless steel three-wire series-arc cladding (L-S orientation)

8 Tensile properties of three-wire series-arc cladding specimens in the $L$ orientation

9 Unloading compliance J-R test results of as-received and thermally aged 12.7-mm-thick three-wire stainless steel cladding fracture toughness specimens ( $10 \%$ side-grooved on each side)

10 Unloading compliance $\mathrm{J}-\mathrm{R}$ test results of as-received and thermally aged 12.7-mm-thick three-wire stainless steel cladding fracture toughness specimens (10\% side-grooved on each side) 


\section{Acknowledgments}

The authors would like to thank John J. Henry, Jr., Eric T. Manneschmidt, and Ronald L. Swain for performing the tensile, Charpy impact, and fracture toughness tests. The effort of Julia L. Bishop in preparing the original manuscript of this report is greatly appreciated. The authors also thank Kathy Spence for editing and Susie Monday and Beverly Wheble for final report preparation. 



\section{Previous Reports in Series}

The work reported here was performed at the Oak Ridge National Laboratory (ORNL) under the Heavy-Section Steel Irradiation (HSSI) Program, W. R. Corwin, Program Manager. The program is sponsored by the Office of Nuclear Regulatory Research of the U.S. Nuclear Regulatory Commission (NRC). The technical monitor for the NRC is M. G. Vassilaros.

This report is designated HSSI Report 13. Reports in this series are listed below:

1. F. M. Haggag , W. R. Corwin, and R. K. Nanstad, Martin Marietta Energy Systems, Inc., Oak Ridge Natl. Lab., Oak Ridge, Tenn., Irradiation Effects on Strength and Toughness of Three-Wire Series-Arc Stainless Steel Weld Overlay Cladding, USNRC Report NUREG/CR-5511 (ORNL/TM-11439), February 1990.

2. L. F. Miller, C. A. Baldwin, F. W. Stallman, and F. B. K. Kam, Martin Marietta Energy Systems, Inc., Oak Ridge Natl. Lab., Oak Ridge, Tenn., Neutron Exposure Parameters for the Metallurgical Test Specimens in the Sixth Heavy-Section Steel Irradiation Series, USNRC Report NUREG/CR-5409 (ORNLTM-11267), March 1990.

3. S. K. Iskander, W. R. Corwin, and R. K. Nanstad, Martin Marietta Energy Systems, Inc., Oak Ridge Natl. Lab., Oak Ridge, Tenn., Results of Crack-Arrest Tests on Two Irradiated High-Copper Welds, USNRC Report NUREG/CR-5584 (ORNLTM-11575), December 1990.

4. R. K. Nanstad and R. G. Berggren, Martin Marietta Energy Systems, Inc., Oak Ridge Natl. Lab., Oak Ridge, Tenn., Irradiation Effects on Charpy Impact and Tensile Properties of Low Upper-Shelf Welds, HSSI Series 2 and 3, USNRC Report NUREG/CR-5696 (ORNLTM-11804), August 1991.

5. R. E. Stoller, Martin Marietta Energy Systems, Inc., Oak Ridge Natl. Lab., Oak Ridge, Tenn., Modeling the Influence of Irradiation Temperature and Displacement Rate on Radiation-Induced Hardening in Ferritic Steels, USNRC Report NUREG/CR-5859 (ORNL/TM-12703), August 1992.

6. R. K. Nanstad, D. E. McCabe, and R. L. Swain, Martin Marietta Energy Systems, Inc., Oak Ridge Natl. Lab., Oak Ridge, Tenn., Chemical Composition $R_{\text {NOT }}$ Determinations for Midland Weld WF-70, USNRC Report NUREG/CR-5914 (ORNL-6740), December 1992.

7. R. K. Nanstad, F. M. Haggag, D. E. McCabe, S. K. Iskander, K. O. Bowman, and B. H. Menke, Martin Marietta Energy Systems, Inc., Oak Ridge Natl. Lab., Oak Ridge, Tenn., Irradiation Effects on Fracture Toughness of Two High-Copper Submerged-Arc Welds, USNRC Report NUREG/CR-5913 (ORNLTM-12156N1), October 1992.

8. S. K. Iskander, W. R. Corwin, and R. K. Nanstad, Martin Marietta Energy Systems, Inc., Oak Ridge Natl. Lab., Oak Ridge, Tenn., Crack-Arrest Tests on Two Irradiated High-Copper Welds, USNRC Report NUREG/CR-6139 (ORNL/TM-12513), March 1994.

9. R. E. Stoller, Martin Marietta Energy Systems, Inc., Oak Ridge Natl. Lab., Oak Ridge, Tenn., A Comparison of the Relative Importance of Copper Precipitates and Point Defects in Reactor Pressure Vessel Embrittlement, USNRC Report NUREG/CR-6231 (ORNL/TM-6811), December 1994.

10. D. E. McCabe, R. K. Nanstad, S. K. Iskander, and R. L. Swain, Martin Marietta Energy Systems, Inc., Oak Ridge Natl. Lab., Oak Ridge, Tenn., Unirradiated Material Properties of Midland Weld WF-70, USNRC Report NUREG/CR-6249 (ORNLTM-12777), October 1994.

11. P. M. Rice and R. E. Stoller, Lockheed Martin Energy Systems, Oak Ridge Natl. Lab., Oak Ridge, Tenn., Microstructural Characterization of Selected AEAUCSB Model FeCuMn Alloys, USNRC Report NUREG/CR-6332 (ORNLTM-12980), to be published. 
12. J. H. Giovanola and J. E. Crocker, SRI International, Fracture Toughness Testing with Cracked Round Bars: Feasibility Study, USNRC Report NUREG/CR-6342 (ORNL/SUB/94-DHK60), to be published.

13. This report.

The HSSI Program includes both follow-on and the direct continuation of work that was performed under the Heavy-Section Steel Technology (HSST) Program. Previous HSST reports related to irradiation effects in pressure vessel materials and those containing unirradiated properties of materials used in HSSI and HSST irradiation programs are tabulated below as a convenience to the reader.

C. E. Childress, Union Carbide Corp. Nuclear Div., Oak Ridge Natl. Lab., Oak Ridge, Tenn., Fabrication History of the First Two 12-in.-Thick A-533 Grade B, Class 1 Steel Plates of the Heavy-Section Steel Technology Program, ORNL-4313, February 1969.

T. R. Mager and F. O. Thomas, Westinghouse Electric Corporation, PWR Systems Division, Pittsburgh, Pa., Evaluation by Linear Elastic Fracture Mechanics of Radiation Damage to Pressure Vesse/ Steels, WCAP-7328 (Rev.), October 1969.

P. N. Randall, TRW Systems Group, Redondo Beach, Calif., Gross Strain Measure of Fracture Toughness of Steels, HSSTP-TR-3, Nov. 1, 1969.

L. W. Loechel, Martin Marietta Corporation, Denver, Colo., The Effect of Testing Variables on the Transition Temperature in Steel, MCR-69-189, Nov. 20, 1969.

W. O. Shabbits, W.H. Pryle, and E. T. Wessel, Westinghouse Electric Corporation, PWR Systems Division, Pittsburgh, Pa., Heavy-Section Fracture Toughness Properties of A533 Grade B Class 1 Steel Plate and Submerged Arc Weldment, WCAP-7414, December 1969.

C. E. Childress, Union Carbide Corp. Nuclear Div., Oak Ridge Natt. Lab., Oak Ridge, Tenn., Fabrication History of the Third and Fourth ASTM A-533 Steel Plates of the Heavy-Section Steel Technology Program, ORNL-4313-2, February 1970.

P. B. Crosley and E. J. Ripling, Materials Research Laboratory, Inc., Glenwood, III., Crack Arrest Fracture Toughness of A533 Grade B Class 1 Pressure Vessel Steel, HSSTP-TR-8, March 1970.

F. J. Loss, Naval Research Laboratory, Washington., D.C., Dynamic Tear Test Investigations of the Fracture Toughness of Thick-Section Steel, NRL-7056, May 14, 1970.

T. R. Mager, Westinghouse Electric Corporation, PWR Systems Division, Pittsburgh, Pa., Post-Irradiation Testing of $2 T$ Compact Tension Specimens, WCAP-7561, August 1970.

F. J. Witt and R. G. Berggren, Union Carbide Corp. Nuclear Div., Oak Ridge Natl. Lab., Oak Ridge, Tenn., Size Effects and Energy Disposition in Impact Specimen Testing of ASTM A533 Grade B Steel, ORNLTM-3030, August 1970.

D. A. Canonico, Union Carbide Corp. Nuclear. Div., Oak Ridge Natl. Lab., Oak Ridge, Tenn., Transition Temperature Considerations for Thick-Wall Nuclear Pressure Vessels, ORNLTM-3114, October 1970.

T. R. Mager, Westinghouse Electric Corporation, PWR Systems Division, Pittsburgh, Pa., Fracture Toughness Characterization Study of A533, Grade B, Class 1 Steel, WCAP-7578, October 1970.

W. O. Shabbits, Westinghouse Electric Corporation, PWR Systems Division, Pittsburgh, Pa., Dynamic Fracture Toughness Properties of Heavy-Section A533 Grade B Class 1 Steel Plate, WCAP-7623, December 1970. 
C. E. Childress, Union Carbide Corp. Nuclear Div., Oak Ridge Natt. Lab., Oak Ridge, Tenn., Fabrication Procedures and Acceptance Data for ASTM A-533 Welds and a 10-in.-Thick ASTM A-533 Plate of the Heavy-Section Steel Technology Program, ORNL-TM-4313-3, January 1971.

D. A. Canonico and R. G. Berggren, Union Carbide Corp. Nuclear Div., Oak Ridge Natl. Lab., Oak Ridge, Tenn., Tensile and Impact Properties of Thick-Section Plate and Weldments, ORNLTM-3211, January 1971.

C. W. Hunter and J. A. Williams, Hanford Eng. Dev. Lab., Richland, Wash., Fracture and Tensile Behavior of Neutron-Irradiated A533-B Pressure Vessel Steel, HEDL-TME-71-76, Feb. 6, 1971.

C. E. Childress, Union Carbide Corp. Nuclear Div., Oak Ridge Natl. Lab., Oak Ridge, Tenn., Manual for ASTM A533 Grade B Class 1 Steel (HSST Plate 03) Provided to the International Atomic Energy Agency, ORNLTM-3193, March 1971.

P. N. Randall, TRW Systems Group, Redondo Beach, Calif., Gross Strain Crack Tolerance of A533-B Steel, HSSTP-TR-14, May 1, 1971.

C. L. Segaser, Union Carbide Corp. Nuclear Div., Oak Ridge Natl. Lab., Oak Ridge, Tenn., Feasibility Study, Irradiation of Heavy-Section Steel Specimens in the South Test Facility of the Oak Ridge Research Reactor, ORNLTM-3234, May 1971.

H. T. Corten and R. H. Sailors, University of Illinois, Urban, III., Relationship Between Material Fracture Toughness Using Fracture Mechanics and Transition Temperature Tests, T\&AM Report 346, Aug. 1, 1971.

L. A. James and J. A. Williams, Hanford Eng. Dev. Lab., Richland, Wash., Heavy-Section Steel Technology Program Technical Report No. 21, The Effect of Temperature and Neutron Iradiation Upon the Fatigue-Crack Propagation Behavior of ASTM A533 Grade B, Class 1 Steel, HEDL-TME 72-132, September 1972.

P. B. Crosley and E. J. Ripling, Materials Research Laboratory, Inc., Glenwood, III., Crack Arrest in an Increasing K-FieJd, HSSTP-TR-27, January 1973.

W. J. Stelzman and R. G. Berggren, Union Carbide Corp. Nuclear Div., Oak Ridge Natl. Lab., Oak Ridge, Tenn., Radiation Strengthening and Embrittlement in Heavy-Section Steel Plates and Welds, ORNL-4871, June 1973.

J. M. Steichen and J. A. Williams, Hanford Eng. Dev. Lab., Richland, Wash., High Strain Rate Tensile Properties of Irradiated ASTM A533 Grade B Class 1 Pressure Vessel Steel, HEDL-TME 73-74, July 1973.

J. A. Williams, Hanford Eng. Dev. Lab., Richland, Wash., The Irradiation and Temperature Dependence of Tensile and Fracture Properties of ASTM A533, Grade B, Class 1 Steel Plate and Weldment, HEDL-TME 73-75, August 1973.

J. A. Williams, Hanford Eng. Dev. Lab., Richland, Wash., Some Comments Related to the Effect of Rate on the Fracture Toughness of Irradiated ASTM A553-B Steel Based on Yield Strength Behavior, HEDL-SA 797, December 1974.

J. A. Williams, Hanford Eng. Dev. Lab., Richland, Wash., The Iradiated Fracture Toughness of ASTM A533, Grade B, Class 1 Steel Measured with a Four-Inch-Thick Compact Tension Specimen, HEDL-TME 75-10, Januany 1975.

J. G. Merkle, G. D. Whitman, and R. H. Bryan, Union Carbide Corp. Nuclear Div., Oak Ridge Natl. Lab., Oak Ridge, Tenn., An Evaluation of the HSST Progam Intermediate Pressure Vessel Tests in Terms of Light-Water-Reactor Pressure Vessel Safety, ORNLTM-5090, November 1975.

J. A. Davidson, L. J. Ceschini, R. P. Shogan, and G. V. Rao, Westinghouse Electric Corporation, PWR Systems Division, Pittsburgh, Pa., The Irradiated Dynamic Fracture Toughness of ASTM A533, Grade B, Class 1 Steel Plate and Submerged Arc Weldment, WCAP-8775, October 1976. 
J. A. Williams, Hanford Eng. Dev. Lab., Richland, Wash., Tensile Properties of Irradiated and Unirradiated Welds of A533 Steel Plate and A508 Forgings, USNRC Report NUREG/CR-1158 (ORNL/SUB-79/50917/2), July 1979.

J. A. Williams, Hanford Eng. Dev. Lab., Richland, Wash., The Ductile Fracture Toughness of Heavy-Section Steel Plate, USNRC Report NUREG/CR-0859, September 1979.

K. W. Carlson and J. A. Williams, Hanford Eng. Dev. Lab., Richland, Wash., The Effect of Crack Length and Side Grooves on the Ductile Fracture Toughness Properties of ASTM A533 Steel, USNRC Report NUREG/CR-1171 (ORNL/SUB-79/50917/3), October 1979.

G. A. Clarke, Westinghouse Electric Corp., PWR Systems Division, Pittsburgh, Pa., An Evaluation of the Unloading Compliance Procedure for J-Integral Testing in the Hot Cell, Final Report, USNRC Report NUREG/CR-1070 (ORNL/SUB-7394/1), October 1979.

P. B. Crosley and E. J. Ripling, Materials Research Laboratory, Inc., Glenwood, III., Development of a Standard Test for Measuring $K_{\text {to }}$ with a Modified Compact Specimen, USNRC Report NUREG/CR-2294 (ORNL/SUB-81/7755/1), August 1981.

H. A. Domian, Babcock and Wilcox Company, Alliance, Ohio, Vessel V-8 Repair and Preparation of Low UpperShelf Weldment, USNRC Report NUREG/CR-2676 (ORNL/SUB/81-85813/1), June 1982.

R. D. Cheverton, S. K. Iskander, and D. G. Ball, Union Carbide Corp. Nuclear Div., Oak Ridge Natl. Lab., Oak Ridge, Tenn., PWR Pressure Vessel Integrity During Overcooling Accidents: A Parametric Analysis, USNRC Report NUREG/CR-2895 (ORNLTM-7931), February 1983.

J. G. Merkle, Union Carbide Corp. Nuclear Div., Oak Ridge Natl. Lab., Oak Ridge, Tenn., An Examination of the Size Effects and Data Scatter Observed in Small Specimen Cleavage Fracture Toughness Testing, USNRC Report NUREG/CR-3672 (ORNL/TM-9088), April 1984.

W. R. Corwin, Martin Marietta Energy Systems, Inc., Oak Ridge Natl. Lab., Oak Ridge, Tenn., Assessment of Radiation Effects Relating to Reactor Pressure Vessel Cladding, USNRC Report NUREG/CR-3671 (ORNL-6047), July 1984.

W. R. Corwin, R. G. Berggren, and R. K. Nanstad, Martin Marietta Energy Systems, Inc., Oak Ridge Natl. Lab., Oak Ridge, Tenn., Charpy Toughness and Tensile Properties of a Neutron Irradiated Stainless Steel SubmergedArc Weld Cladding Overlay, USNRC Report NUREG/CR-3927 (ORNLTM-9709), September 1984.

J. J. McGowan, Martin Marietta Energy Systems, Inc., Oak Ridge Natl. Lab., Oak Ridge, Tenn., Tensile Properties of Irradiated Nuclear Grade Pressure Vessel Plate and Welds for the Fourth HSST Irradiation Series, USNRC Report NUREG/CR-3978 (ORNL/TM-9516), January 1985.

J. J. McGowan, Martin Marietta Energy Systems, Inc., Oak Ridge Natl. Lab., Oak Ridge, Tenn., Tensile Properties of Irradiated Nuclear Grade Pressure Vessel Welds for the Third HSST Irradiation Series, USNRC Report NUREG/CR-4086 (ORNL/M-9477), March 1985.

W. R. Conwin, G. C. Robinson, R. K. Nanstad, J. G. Merkle, R. G. Berggren, G. M. Goodwin, R. L. Swain, and T. D. Owings, Martin Marietta Energy Systems, Inc., Oak Ridge Natl. Lab., Oak Ridge, Tenn., Effects of Stainless Steel Weld Overlay Cladding on the Structural Integrity of Flawed Steel Plates in Bending, Series 1, USNRC Report NUREG/CR-4015 (ORNLTM-9390), April 1985.

W. J. Stelzman, R. G. Berggren, and T. N. Jones, Martin Marietta Energy Systems, Inc., Oak Ridge Natt. Lab., Oak Ridge, Tenn., ORNL Characterization of Heavy-Section Steel Technology Program Plates 01, 02, and 03, USNRC Report NUREG/CR-4092 (ORNLTM-9491), April 1985. 
G. D. Whitman, Martin Marietta Energy Systems, Inc., Oak Ridge Natl. Lab., Oak Ridge, Tenn., Historical Summary of the Heavy-Section Steel Technology Program and Some Related Activities in Light-Water Reactor Pressure Vessel Safety Research, USNRC Report NUREG/CR-4489 (ORNL-6259), March 1986.

R. H. Bryan, B. R. Bass, S. E. Bolt, J. W. Bryson, J. G. Merkle, R. K. Nanstad, and G. C. Robinson, Martin Marietta Energy Systems, Inc., Oak Ridge Natt. Lab., Oak Ridge, Tenn., Test of 6-in.-Thick Pressure Vessels. Series 3: Intermediate Test Vessel V-8A-Tearing Behavior of Low Upper-Shelf Material, USNRC Report NUREG-CR-4760 (ORNL-6187), May 1987.

D. B. Barker, R. Chona, W. L. Fourney, and G. R. Irwin, University of Maryland, College Park, Md., A Report on the Round Robin Program Conducted to Evaluate the Proposed ASTM Standard Test Method for Determining the Plane Strain Crack Arrest Fracture Toughness, $\mathrm{K}_{\mathrm{ta}}$, of Ferritic Materials, USNRC Report NUREG/CR-4966 (ORNL/SUB/79-7778/4), January 1988.

L. F. Miller, C. A. Baldwin, F. W. Stallman, and F. B. K. Kam, Martin Marietta Energy Systems, Inc., Oak Ridge Natl. Lab., Oak Ridge, Tenn., Neutron Exposure Parameters for the Metallurgical Test Specimens in the Fifth HeavySection Steel Technology Irradiation Series Capsules, USNRC Report NUREG/CR-5019 (ORNLTM-10582), March 1988.

J. J. McGowan, R. K. Nanstad, and K. R. Thoms, Martin Marietta Energy Systems, Inc., Oak Ridge Natl. Lab., Oak Ridge, Tenn., Characterization of Irradiated Current-Practice Welds and A533 Grade B Class 1 Plate for Nuclear Pressure Vessel Service, USNRC Report NUREG/CR-4880 (ORNL-6484N1 and V2), July 1988.

R. D. Cheverton, W. E. Pennell, G. C. Robinson, and R. K. Nanstad, Martin Marietta Energy Systems, Inc., Oak Ridge Natl. Lab., Oak Ridge, Tenn., Impact of Radiation Embrittlement on Integrity of Pressure Vessel Supports for Two PWR Plants, USNRC Report NUREG/CR-5320 (ORNLTM-10966), February 1989.

J. G. Merkle, Martin Marietta Energy Systems, Inc., Oak Ridge Natl. Lab., Oak Ridge, Tenn., An Overview of the Low-Upper-Shelf Toughness Safety Margin Issue, USNRC Report NUREG/CR-5552 (ORNLTM-11314), August 1990.

R. D. Cheverton, T. L. Dickson, J. G. Merkle, and R. K. Nanstad, Martin Marietta Energy Systems, Inc., Oak Ridge Natl. Lab., Oak Ridge, Tenn., Review of Reactor Pressure Vessel Evaluation Report for Yankee Rowe Nuclear Power Station (YAEC No. 1735), USNRC Report NUREG/CR-5799 (ORNLTM-11982), March 1992. 


\title{
Effects of Thermal Aging and Neutron Irradiation on the Mechanical Properties of Three-Wire Stainless Steel Weld Overlay Cladding*
}

\author{
Fahmy M. Haggag and Randy K. Nanstad
}

\section{Introduction}

Thermal aging at a relatively low temperature $\left(343^{\circ} \mathrm{C}\right)$ has been shown to significantly degrade the Charpy impact toughness of type 308 stainless steel shielded metal-arc (SMA) welds.' The stainless steel cladding applied to the inner surface of some reactor pressure vessels (RPVs) is similar to this material, although the cladding is a submerged arc (series-arc) weld overlay. Hence, an experimental program was initiated at Oak Ridge National Laboratory (ORNL) to evaluate the effects of thermal aging on stainless steel cladding as well as its contribution to toughness degradation during irradiation experiments. Neutron irradiation effects on three-wire stainless steel cladding were studied, and detailed results are given elsewhere ${ }^{2-4}$ and briefly summarized here. The goals of the thermal aging studies were to quantify and separate the damage contributions of thermal aging and neutron irradiation for short-term exposures and to evaluate the effects of aging for long-term exposures. Since the irradiation to the highest fluence of $5 \times 10^{19}$ neutrons $/ \mathrm{cm}^{2}\left(>1 \mathrm{MeV}\right.$ ) was conducted at $288^{\circ} \mathrm{C}$ for $1605 \mathrm{~h}$, tensile, Charpy V-notch (CVN), and compact fracture toughness specimens were thermally aged as discussed in the thermal aging plan described below. This report summarizes the experimental plan and presents the results of short-term thermal aging at $288^{\circ} \mathrm{C}$ for $1605 \mathrm{~h}$, together with comparisons to neutron irradiation effects. Also, results of tensile, CVN, and compact fracture toughness specimens, thermally aged for $20,000 \mathrm{~h}$ at 288 or $343^{\circ} \mathrm{C}$, are presented here. Additional material is currently being aged at $288^{\circ} \mathrm{C}$ for longer times $(50,000 \mathrm{~h}$ and greater).

\footnotetext{
"Research was sponsored by the Office of Nuclear Regulatory Research, Division of Engineering Technology, U. S. Nuclear Regulatory Commission, under Interagency Agreement DOE 1886-8109-8L with the U.S. Department of Energy under contract DE-AC05-960R22464 with Lockheed Martin Energy Research Corporation.
} 


\section{Experimental Procedures}

Stainless steel weld overlay cladding was fabricated using the three-wire series-arc method. The three-wire cladding material was produced by Combustion Engineering, Inc., Chattanooga, Tennessee. Various combinations of types 304, 308, and 309 stainless steel wires were used to produce three layers of cladding (approximately $20 \mathrm{~mm}$ total thickness). Details of the three-wire series-arc cladding procedure, postweld heat treatment (PWHT) etc., are given in reference 4. Three layers of cladding were applied to a pressure vessel plate to provide adequate thickness (approximately $20 \mathrm{~mm}$ ) for the fabrication of test specimens. The chemical composition of the cladding is given in Table 1. After a PWHT $\left(40 \mathrm{~h}\right.$ at $\left.621^{\circ} \mathrm{C}\right)$, the cladding material was thermally aged at $288^{\circ} \mathrm{C}$ for 1605 and $20,000 \mathrm{~h}$. Another set of cladding specimens was aged at $343^{\circ} \mathrm{C}$ for $20,000 \mathrm{~h}$. Testing of tensile, CVN, and 12.7-mm-thick compact [0.5T C(T)] fracture toughness specimens was conducted according to American Society for Testing and Materials (ASTM) Standards E 8-89, E 184-79, and E 813-89, respectively. Precracked CVN (PCVN) specimens were also thermally aged; the dynamic fracture toughess $\left(K_{\mathrm{ta}}\right)$ test results will be reported in another report. The thermal aging plan that describes aging temperatures and times is given below. Irradiation conditions $\left[2 \times 10^{19}\right.$ neutrons $\left./ \mathrm{cm}^{2}(>1 \mathrm{MeV}), 288^{\circ} \mathrm{C}\right]$ are given in references 4 and 5 .

\subsection{Thermal Aging Plan}

Pieces and specimens from three-wire series-arc stainless steel cladding were thermally aged in air in two separate furnaces as discussed below. Several thermocouples were spot welded to the specimens, and aging temperatures were recorded daily:

1. Aging temperature of $288^{\circ} \mathrm{C}\left(550^{\circ} \mathrm{F}\right)$ for times of $1605,20,000,50,000 \mathrm{~h}$, and greater. The aging time of $1650 \mathrm{~h}$ is equal to the irradiation time of the high-fluence $\left[5 \times 10^{19}\right.$ neutrons $\left./ \mathrm{cm}^{2}(>1 \mathrm{MeV})\right]$ specimens to enable us to separate the effects of thermal aging from those of neutron embrittlement. Also, the various aging times will provide data on effects of thermal aging versus time. The 1605- and 20,000-h aging sets were completed, and their test results are presented in this report while the $50,000-\mathrm{h}$ and greater agings are still in progress.

2 Aging temperature of $343^{\circ} \mathrm{C}\left(650^{\circ} \mathrm{F}\right)$ for $20,000 \mathrm{~h}$ to compare with specimens from type 308 stainless steel welds thermally aged and tested earlier. ${ }^{1}$ Additional pieces from type 308 stainless steel welds were also aged for $50,000 \mathrm{~h}$. Results of aged three-wire cladding specimens are presented in this report, while the results of type 308 stainless steel weld specimens will be presented in another report.

Both thermal aging series above included several round tensile, CVN impact, PCVN, and 12.7-mm-thick compact [0.5T C $(T)]$ fracture toughness specimens. All specimens have an $L-S$ orientation ( $L$ is the welding direction).

\section{Results and Discussion}

The effects of neutron irradiation and thermal aging alone at $288^{\circ} \mathrm{C}$ for $1605 \mathrm{~h}$ on impact, tensile, and fracture toughness properties are described and discussed first. The effects of thermal aging for $20,000 \mathrm{~h}$ at 288 and $343^{\circ} \mathrm{C}$ are presented later.

\subsection{Effects of Neutron Irradiation and Thermal Aging at $288^{\circ} \mathrm{C}$ for $1605 \mathrm{~h}$}

\subsubsection{Charpy Impact Properties}

All cladding exhibited ductile-to-brittle transition behavior during Charpy impact testing due to the dominance of $\delta$-ferrite failures at low temperatures. ${ }^{6}$ The CVN test results fitted with a hyperbolic tangent function for the 
Table 1. Chemical composition of the three-wire stainless steel weld clad overlay used in Phase 2 of the Seventh Irradiation Series

\begin{tabular}{|c|c|c|c|c|c|c|c|c|c|c|c|}
\hline \multirow{2}{*}{ Layer } & \multicolumn{11}{|c|}{$\begin{array}{c}\text { Content } \\
\text { (wt \%) }\end{array}$} \\
\hline & C & $\mathrm{Cr}$ & $\mathrm{Ni}$ & Mo & $\mathrm{Mn}$ & $\mathbf{S i}$ & Co & $\mathrm{Cu}$ & V & $P$ & $s$ \\
\hline Lower & 0.052 & 19.75 & 9.75 & 0.18 & 1.59 & 0.63 & 0.03 & 0.07 & 0.03 & 0.016 & 0.014 \\
\hline Middle & 0.049 & 19.38 & 9.18 & 0.23 & 1.28 & 0.78 & 0.07 & 0.36 & 0.06 & 0.023 & 0.017 \\
\hline Upper & 0.049 & 19.34 & 9.04 & 0.23 & 1.34 & 0.82 & 0.08 & 0.39 & 0.06 & 0.023 & 0.017 \\
\hline
\end{tabular}


as-received (unirradiated), thermally aged at $288^{\circ} \mathrm{C}$, and irradiated specimens are summarized in Table 2. Comparisons of the CVN impact energy and lateral expansion of the three material conditions (as-received, thermally aged, and irradiated) are shown in Figures 1 and 2, respectively. The drop in the upper-shelf energy (USE) for the irradiated specimens [fluence of $5 \times 10^{19}$ neutrons $/ \mathrm{cm}^{2}\left(>1 \mathrm{MeV}\right.$ ), irradiation temperature of $288^{\circ} \mathrm{C}$ ] was $22 \%$ due to the combined effect of neutron irradiation and thermal aging. The USE was reduced by $16 \%$ due to thermal aging exposure. Hence, it appears that the contribution of thermal aging to the CVN upper-shelf drop is large compared to the irradiation damage (16 vs $6 \%$, assuming that the effects of irradiation and thermal aging can simply be added together). Additionally, thermal aging resulted in essentially no shift ( $3^{\circ} \mathrm{C}$ measured shift) of the Charpy impact transition temperature at the 41-J level. This effect of thermal aging on the 41-J transition temperature shift is very small compared to the combined effect during neutron irradiation $\left(3 \mathrm{vs} 29^{\circ} \mathrm{C}\right)$. Also, the lateral expansion upper and lower shelves were lowered due to the thermal aging by 4 and $48 \%$, respectively, compared to the as-received material. However, due to the small number of specimens tested at the lower shelf, the percentage drop of the lateral expansion lower shelf is not rigorous. The drops in the lateral expansion upper and lower shelves after irradiation were 42 and $93 \%$, respectively, compared to the as-received material.

Table 2. Charpy impact test results for stainless steel three-wire series-arc cladding (L-S orientation)

\begin{tabular}{|c|c|c|c|c|c|c|c|}
\hline \multirow{2}{*}{$\begin{array}{l}\text { Material } \\
\text { condition }\end{array}$} & \multicolumn{3}{|c|}{$\begin{array}{l}\text { Transition temperature } \\
\qquad\left({ }^{\circ} \mathrm{C}\right)\end{array}$} & \multicolumn{2}{|c|}{$\begin{array}{l}\text { Energy } \\
(J)\end{array}$} & \multicolumn{2}{|c|}{$\begin{array}{l}\text { Laterial expansion } \\
(\mathrm{mm})\end{array}$} \\
\hline & $41 \mathrm{~J}$ & $68 \mathrm{~J}$ & $0.38 \mathrm{~mm}$ & $\begin{array}{l}\text { Upper } \\
\text { shelf }\end{array}$ & $\begin{array}{l}\text { Lower } \\
\text { shelf }\end{array}$ & Upper & Lower \\
\hline $\begin{array}{l}\text { As-received } \\
\text { Aged }^{b} \\
\text { Irradiated }^{c}\end{array}$ & $\begin{array}{l}-43 \\
-40 \\
-14\end{array}$ & $\begin{array}{r}6 \\
34\end{array}$ & $\begin{array}{l}-51 \\
-65 \\
-9\end{array}$ & $\begin{array}{l}83 \\
70 \\
65\end{array}$ & $\begin{array}{l}14 \\
11 \\
14\end{array}$ & $\begin{array}{l}1.146 \\
1.098 \\
0.666\end{array}$ & $\begin{array}{l}0.229 \\
0.119 \\
0.015\end{array}$ \\
\hline \multicolumn{8}{|c|}{$\begin{array}{l}\text {-Few CVN specimens were tested at the lower shelf; additional specimens could improve the uncertainty of lateral expansion values at the lower } \\
\text { shelf. }\end{array}$} \\
\hline
\end{tabular}




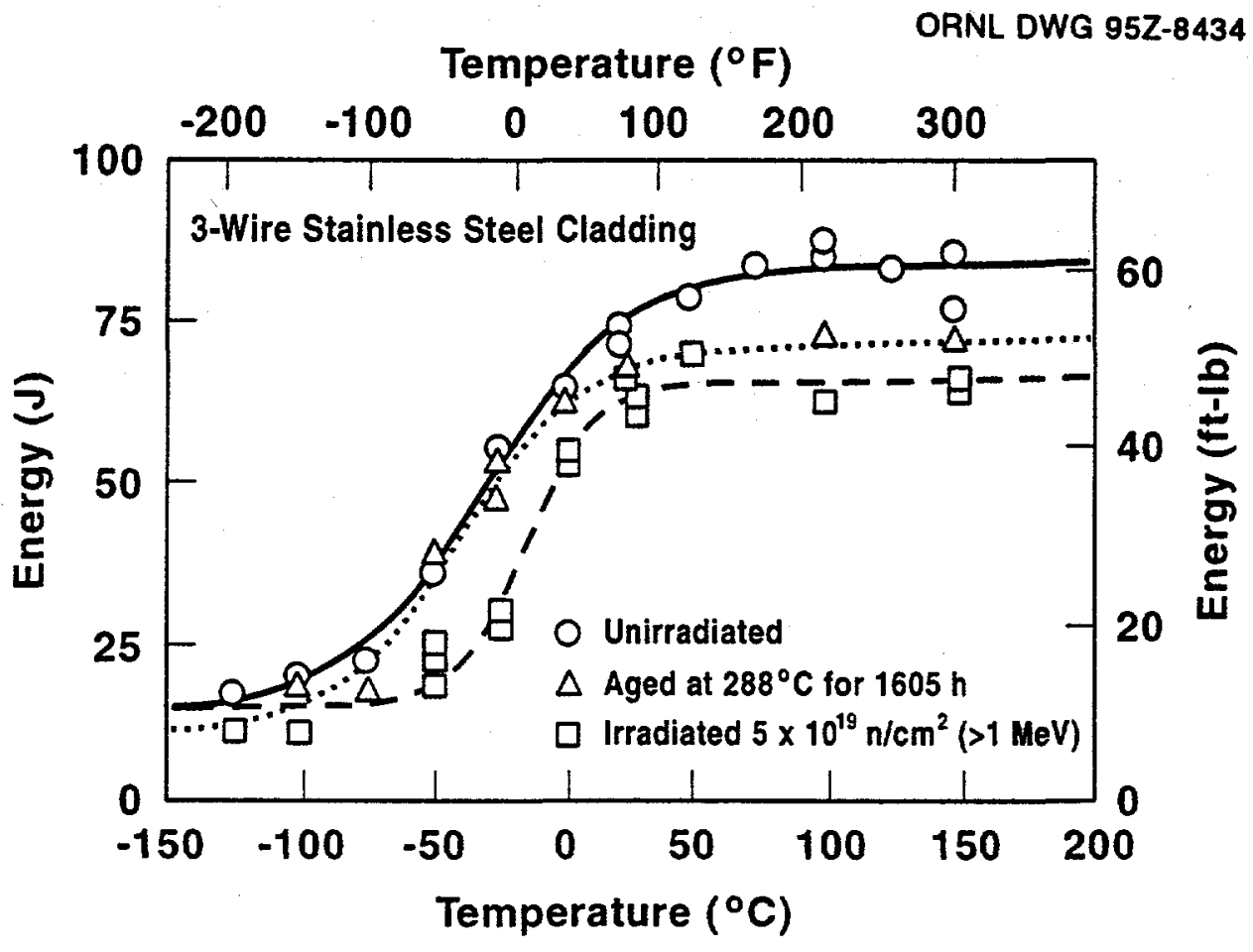

Figure 1. Effects of thermal aging at $288^{\circ} \mathrm{C}$ and neutron irradiation on the Charpy impact energy of three-wire series-arc stainless steel cladding, L-S orientation.

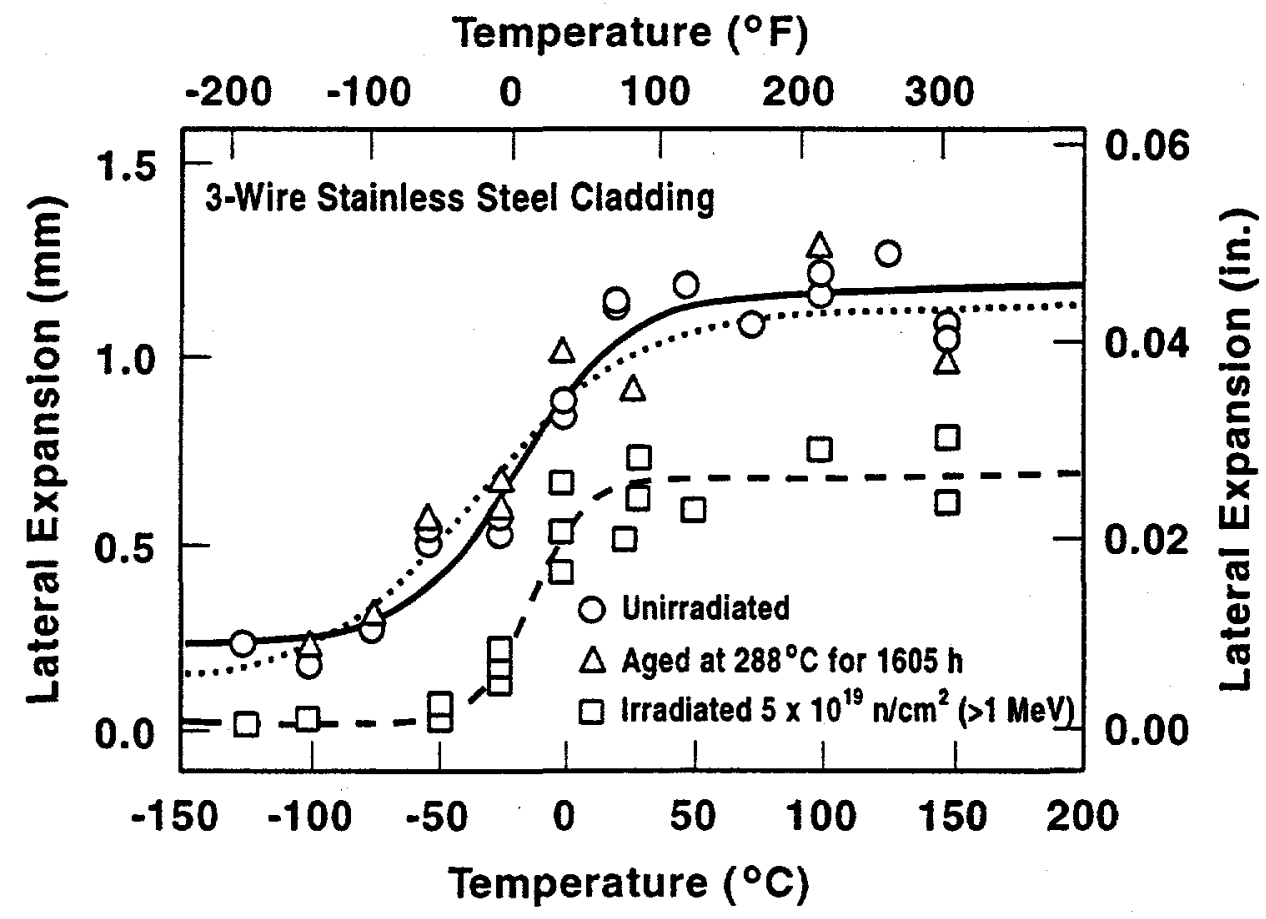

Figure 2. Effects of thermal aging at $288^{\circ} \mathrm{C}$ and neutron irradiation on the Charpy impact lateral expansion of three-wire series-arc stainless steel cladding, L-S orientation. 


\subsubsection{Tensile Properties}

The effect of thermal aging at $288^{\circ} \mathrm{C}$ for $1605 \mathrm{~h}$ on the tensile properties (yield strength, ultimate strength, and total elongation) was very small or negligible. The tensile data for unirradiated, thermally aged (at $288^{\circ} \mathrm{C}$ for $1605 \mathrm{~h}$ ), and irradiated specimens [at $288^{\circ} \mathrm{C}$ to a fluence of $5 \times 10^{19}$ neutrons $/ \mathrm{cm}^{2}(>1 \mathrm{MeV})$ ] are given in Tables 3 through 5. The uniaxial tensile data (yield strength, ultimate strength, and total elongation) for the cladding material in those three conditions are shown in Figures 3 through 5 . The tables and figures show that the increase $(6$ to $34 \%)$ in yield strength of the three-wire stainless steel cladding was due to the neutron irradiation with no appreciable contribution due to short-term thermal aging. The ultimate strength and the total elongation were not affected by irradiation and/or thermal aging.

Table 3. Tensile properties of unirradiated specimens in the $L$ orientation

\begin{tabular}{||c|c|c|c|c||}
\hline \multirow{2}{*}{ Specimen } & \multirow{2}{*}{$\begin{array}{c}\text { Test } \\
\text { temperature } \\
\left({ }^{\circ} \mathrm{C}\right)\end{array}$} & \multicolumn{2}{|c|}{$\begin{array}{c}\text { Tensile strength } \\
(\mathrm{MPa})\end{array}$} & $\begin{array}{c}\text { Total } \\
\text { elongation } \\
(\%)\end{array}$ \\
\cline { 3 - 4 } & & Yield & Ultimate & \\
\hline A16A & -125 & 357 & 1169 & 39 \\
A16B & -125 & 338 & 1150 & 39 \\
A26A & 21 & 301 & 574 & 47 \\
A26B & 21 & 297 & 577 & 47 \\
A20A & 288 & 218 & 409 & 23 \\
A20B & 288 & 252 & 402 & 20 \\
\hline
\end{tabular}

Table 4. Tensile properties of thermally aged $(1605 \mathrm{~h}$ at $288^{\circ} \mathrm{C}$ ) specimens in the L orientation

\begin{tabular}{||c|c|c|c|c||}
\hline \multirow{2}{*}{ Specimen } & $\begin{array}{c}\text { Test } \\
\text { temperature } \\
\left({ }^{\circ} \mathrm{C}\right)\end{array}$ & \multicolumn{2}{|c|}{$\begin{array}{c}\text { Tensile strength } \\
(\mathrm{MPa})\end{array}$} & $\begin{array}{c}\text { Total } \\
\text { elongation } \\
(\%)\end{array}$ \\
\cline { 3 - 4 } & & Yield & Ultimate & \\
\hline A18D & -125 & 360 & 1061 & 38 \\
A24B & -125 & 371 & 1054 & 38 \\
A18A & 25 & 291 & 590 & 47 \\
A18B & 25 & $a$ & 582 & 45 \\
A18C & 288 & 197 & 406 & 28 \\
A24A & 288 & 213 & 401 & 23 \\
\hline a Paper chart recorder of the test machine temporarily stalled in the earlier part of the test. \\
\hline
\end{tabular}


Table 5. Tensile properties of irradiated specimens [at $288^{\circ} \mathrm{C}$ to $5 \times 10^{10}$ neutrons $\left./ \mathrm{cm}^{2}(>1 \mathrm{MeV})\right]$ in the L orientation

\begin{tabular}{||c|c|c|c|c||}
\hline \multirow{2}{*}{ Specimen } & \multirow{2}{*}{$\begin{array}{c}\text { Test } \\
\text { temperature } \\
\end{array}$} & \multicolumn{2}{|c|}{$\begin{array}{c}\text { Tensile strength } \\
(\mathrm{MPa})\end{array}$} & \multirow{2}{*}{$\begin{array}{c}\text { Total } \\
\text { elongation } \\
(\%)\end{array}$} \\
\cline { 3 - 4 } & & Yield & Ultimate & \\
\hline A20C & -125 & 466 & 1072 & 41 \\
A25A & 27 & 333 & 609 & 46 \\
B12A & 27 & 329 & 591 & 47 \\
A25C & 288 & 238 & 433 & 28 \\
B12C & 288 & 242 & 417 & 29 \\
\hline
\end{tabular}

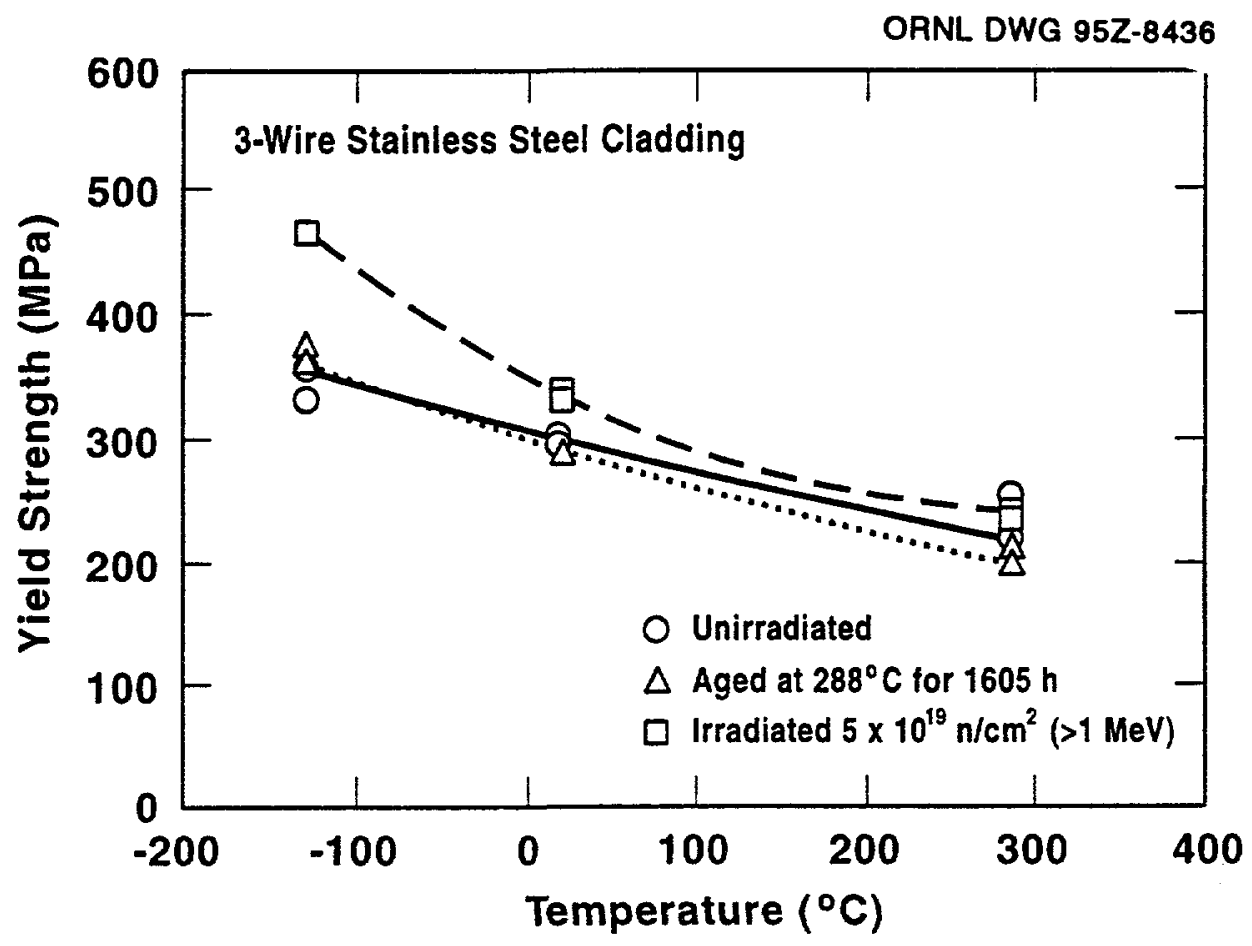

Figure 3. Effects of thermal aging at $288^{\circ} \mathrm{C}$ and neutron irradiation on the yield strength of three-wire series-arc stainless steel cladding. 


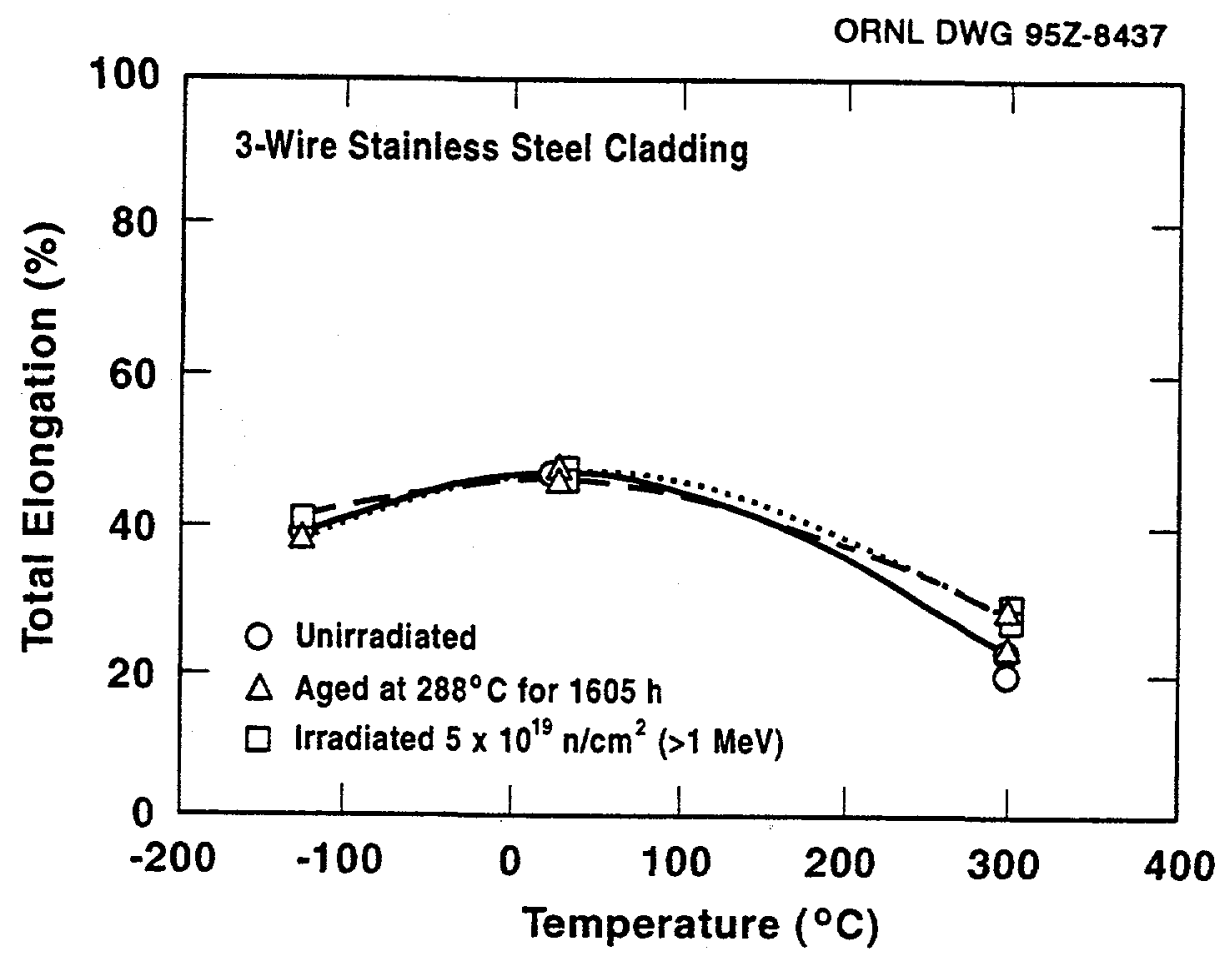

Figure 4. Effects of thermal aging at $288^{\circ} \mathrm{C}$ and neutron irradiation on the ultimate strength of three-wire series-arc stainless steel cladding.

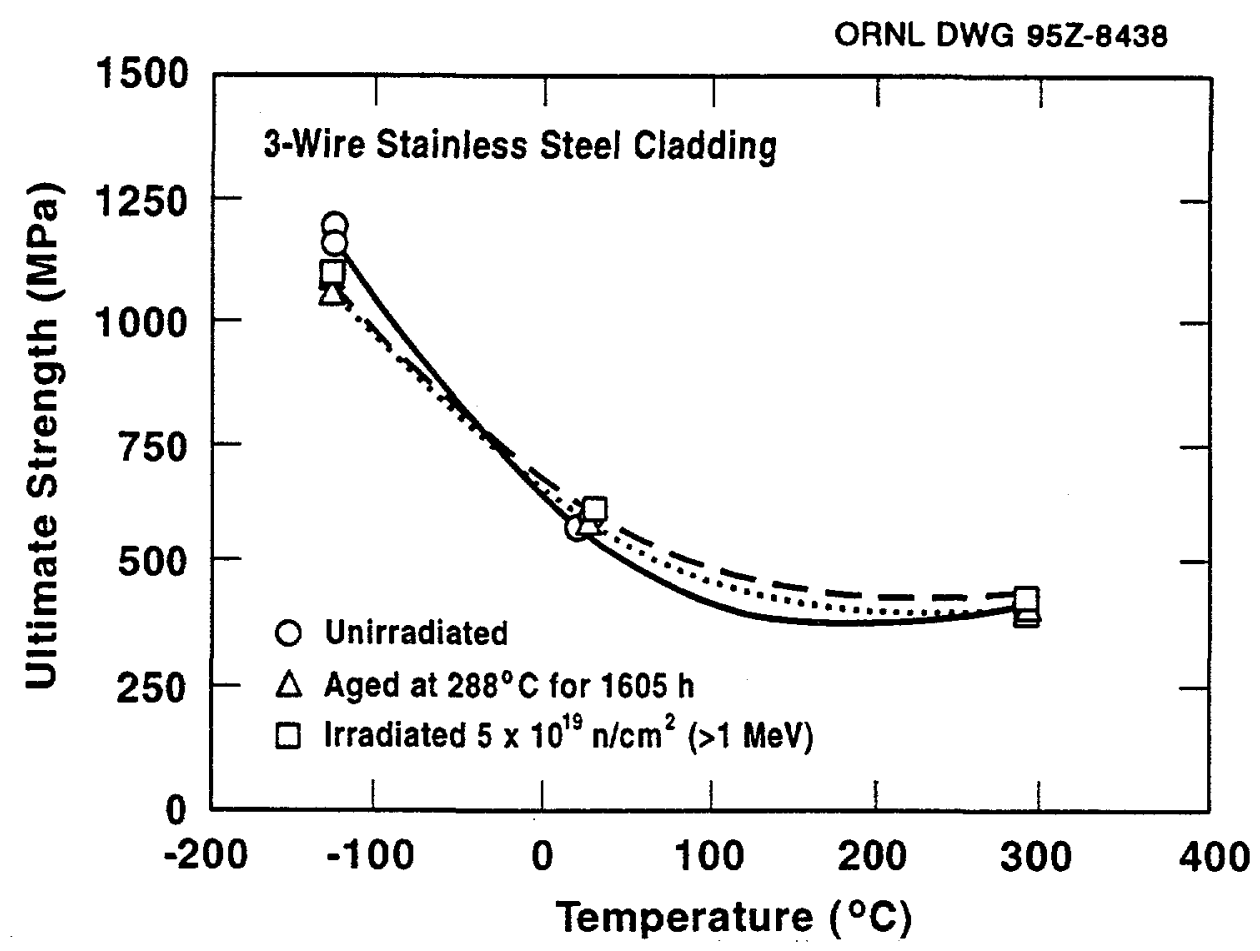

Figure 5. Effects of thermal aging at $288^{\circ} \mathrm{C}$ and neutron irradiation on the total elongation of three-wire series-arc stainless steel cladding. 


\subsubsection{Fracture Toughness}

The test results of 12.7-mm-thick compact [0.5TC(T)] fracture toughness specimens are summarized in Table 6 for the unirradiated, thermally aged $\left(1605 \mathrm{~h}\right.$ at $\left.288^{\circ} \mathrm{C}\right)$, and irradiated $\left[637 \mathrm{~h}\right.$ at $288^{\circ} \mathrm{C}$ to a fluence of $2.4 \times 10^{19}$ neutrons $/ \mathrm{cm}^{2}(>1 \mathrm{MeV}$ ] material conditions. All specimens were 10\% side-grooved on each side and tested using a computerized single-specimen unloading-compliance technique. The deformation $J$-integral values of $J_{k}$ and tearing modulus at various test temperatures are also shown in Figures 6 and 7, respectively. These results indicate that thermal aging reduced the initiation fracture toughness $\left(\mathrm{J}_{1 \mathrm{c}}\right)$ at room temperature and at $120^{\circ} \mathrm{C}$; however, there was no apparent effect at $288^{\circ} \mathrm{C}$. This lack of an effect of thermal aging at $288^{\circ} \mathrm{C}$ for $1605 \mathrm{~h}$ on $\mathrm{J}_{\mathrm{lc}}$ at the test temperature of $288^{\circ} \mathrm{C}$ was also repeated for the $J_{1 c}$ tests following the $20,000-h$ aging, as will be shown later. The effect of thermal aging on the tearing modulus was insignificant (no reduction) for all test temperatures (room temperature, 120 , and $288^{\circ} \mathrm{C}$ ). The low values of $\mathrm{J}_{\mathrm{lc}}$ and tearing modulus for the irradiated cladding (comparable to low upper-shelf ferritic steels sensitive to irradiation) ${ }^{7}$ raise concern about the potential adverse impact of stainless steel cladding on the integrity of a pressure vessel during an overcooling transient (e.g., pressurized thermal shock) in which the growth of small surface flaws can have a significant effect on the probability of vessel failure. This is particularly imporant since cladding failures have occurred in several pressure vessels. ${ }^{8}$ An evaluation of the effects of irradiated stainless steel cladding on the fracture behavior of shallow flaws under pressurized-thermal-shock (PTS) loading has been reported by Keeney-Walker et al. ${ }^{9}$ For pressure and temperature loading histories of the RPV, the authors used an idealization of the Rancho Seco PTS transient. The ductile fracture toughness properties for irradiated cladding (see Figure 6), a relatively low clad yield stress, and the assumption of stress-free cladding at the RPV operating temperature were used to analyze the potential for ductile tearing of the cladding. Under those conditions, results were presented which indicate ductile tearing of the cladding is unlikely to occur for the conditions assumed in the model.

Table 6. Unloading compliance J-R test results of $12.7-\mathrm{mm}$-thick three-wire stainless steel cladding fracture toughness specimens ( $10 \%$ side-grooved on each side)

\begin{tabular}{|c|c|c|c|c|c|c|c|c|c|}
\hline \multirow{2}{*}{$\begin{array}{c}\text { Test } \\
\text { temperature } \\
\left({ }^{\circ} \mathrm{C}\right)\end{array}$} & \multicolumn{3}{|c|}{ Unirradiated } & \multicolumn{3}{|c|}{ Irradiated } & \multicolumn{3}{|c|}{ Aged $^{b}$} \\
\hline & Specimen & $\begin{array}{c}J_{k} \\
\left(k J / m^{2}\right)\end{array}$ & $\begin{array}{l}\text { Tearing } \\
\text { modulus }\end{array}$ & Specimen & $\begin{array}{c}J_{\mathrm{k}} \\
\left(\mathrm{kJ} / \mathrm{m}^{2}\right)\end{array}$ & $\begin{array}{l}\text { Tearing } \\
\text { modulus }\end{array}$ & Specimen & $\begin{array}{c}J_{k} \\
\left(k J / m^{2}\right)\end{array}$ & $\begin{array}{l}\text { Tearing } \\
\text { modulus }\end{array}$ \\
\hline $\begin{array}{l}-75 \\
-75\end{array}$ & $\begin{array}{c}A 13 G \\
\mathrm{H} 2\end{array}$ & $\begin{array}{l}116 \\
145\end{array}$ & $\begin{array}{l}62 \\
35\end{array}$ & $\begin{array}{l}\text { A15F } \\
\text { A15G }\end{array}$ & $\begin{array}{l}79 \\
60\end{array}$ & $\begin{array}{l}29 \\
31\end{array}$ & & & \\
\hline $\begin{array}{l}20 \\
20\end{array}$ & $\begin{array}{l}\text { A13D } \\
\text { A10G }\end{array}$ & $\begin{array}{l}132 \\
169\end{array}$ & $\begin{array}{l}203 \\
159\end{array}$ & & & & $\begin{array}{l}\mathrm{H} 7 \\
\mathrm{H} 8\end{array}$ & $\begin{array}{l}104 \\
144\end{array}$ & $\begin{array}{l}166 \\
182\end{array}$ \\
\hline $\begin{array}{l}30 \\
50\end{array}$ & & & & $\begin{array}{l}\text { A13A } \\
\text { A15C }\end{array}$ & $\begin{array}{l}157 \\
121\end{array}$ & $\begin{array}{l}158 \\
147\end{array}$ & & & \\
\hline $\begin{array}{l}120 \\
120 \\
120\end{array}$ & $\begin{array}{c}\text { A10E } \\
\text { H5 } \\
\text { H3 }\end{array}$ & $\begin{array}{l}136 \\
129 \\
114\end{array}$ & $\begin{array}{l}233 \\
207 \\
214\end{array}$ & A10F & 108 & 161 & $\begin{array}{c}\mathrm{H} 9 \\
\mathrm{AA03}\end{array}$ & $\begin{array}{l}119 \\
94\end{array}$ & $\begin{array}{l}248 \\
282\end{array}$ \\
\hline $\begin{array}{l}200 \\
200\end{array}$ & $\begin{array}{l}\mathrm{H} 6 \\
\mathrm{H} 4\end{array}$ & $\begin{array}{l}95 \\
100\end{array}$ & $\begin{array}{l}220 \\
221\end{array}$ & & & & & & \\
\hline $\begin{array}{l}288 \\
288 \\
288\end{array}$ & $\begin{array}{c}A 15 D \\
A 13 C \\
H 1\end{array}$ & $\begin{array}{l}76 \\
70 \\
83\end{array}$ & $\begin{array}{l}278 \\
171 \\
185\end{array}$ & A15A & 25 & 226 & $\begin{array}{l}\mathrm{H} 10 \\
\text { AA04 } \\
\text { AA02 }\end{array}$ & $\begin{array}{l}85 \\
93 \\
59\end{array}$ & $\begin{array}{l}218 \\
209 \\
230\end{array}$ \\
\hline
\end{tabular}




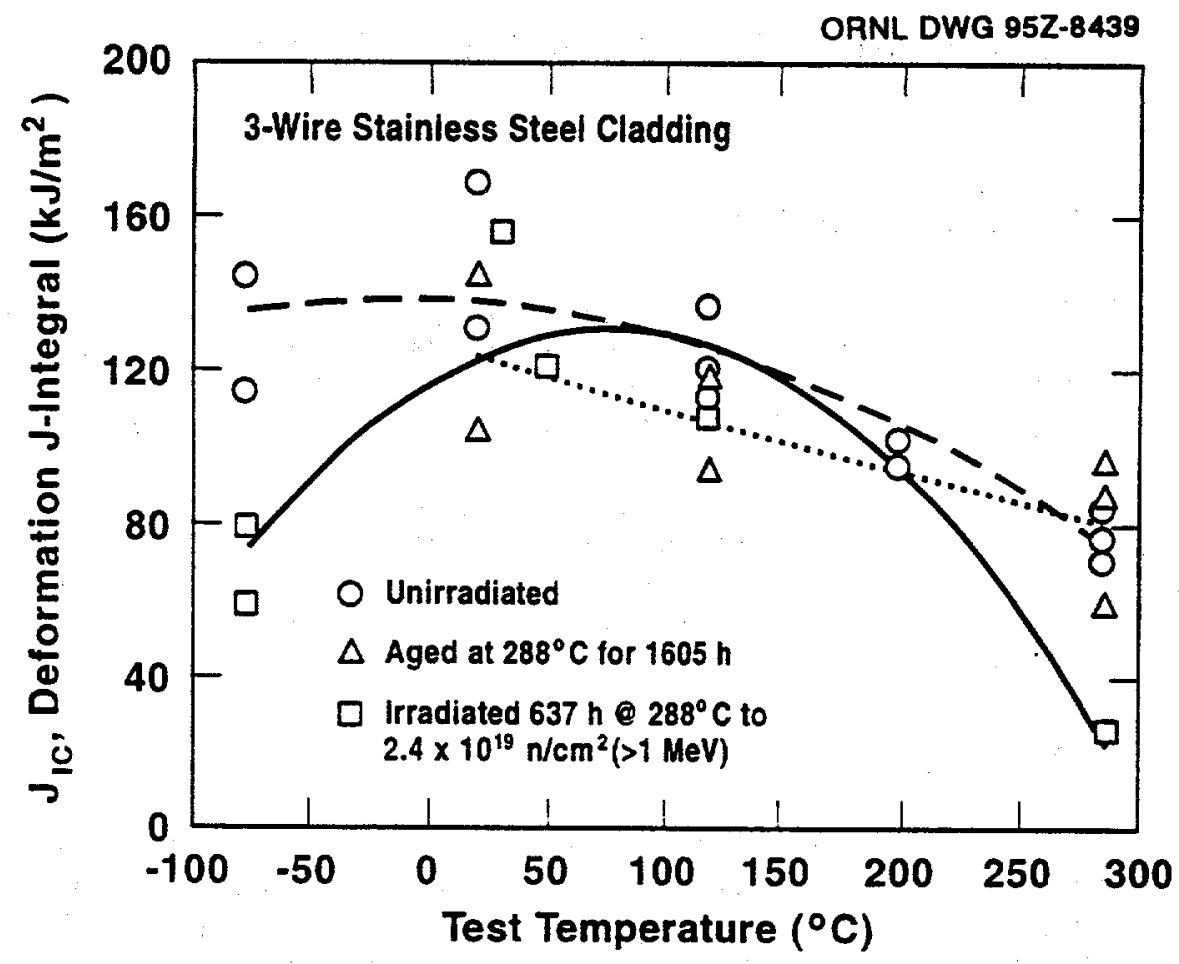

Figure 6. Effects of neutron irradiation and thermal aging at $288^{\circ} \mathrm{C}$ on the initiation fracture toughness, $J_{I C}$, of three-wire stainless steel cladding at various test temperatures.

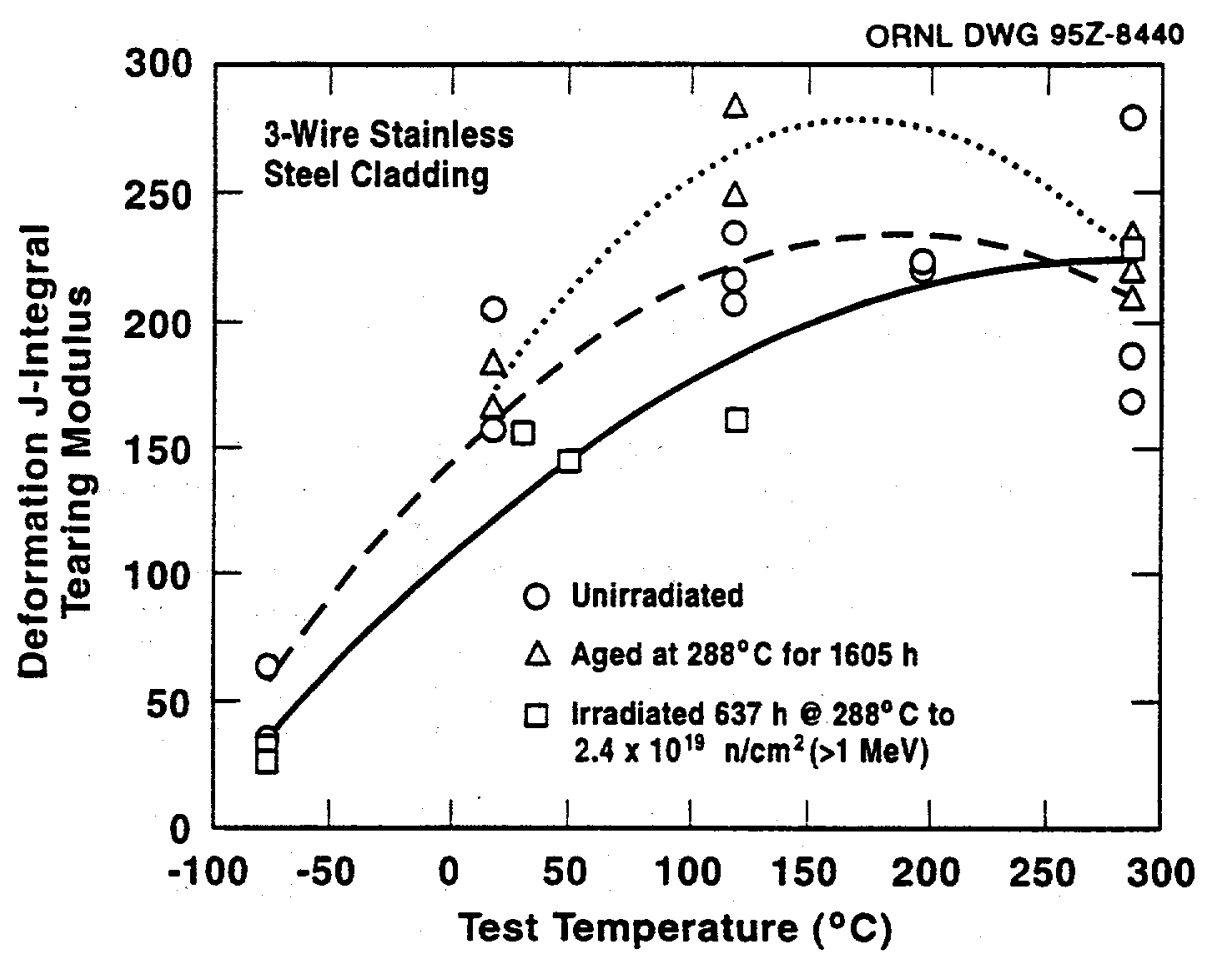

Figure 7. Effects of neutron irradiation and thermal aging at $288^{\circ} \mathrm{C}$ on the deformation J-integral tearing modulus of three-wire stainless steel cladding at various test temperatures. 


\subsection{Effects of Thermal Aging for $20,000 \mathrm{~h}$ at 288 or $343^{\circ} \mathrm{C}$}

\subsubsection{Charpy Impact Properties}

The CVN test results shown in Table 7 indicate that: (1) thermal aging at $288^{\circ} \mathrm{C}$ slightly increased the $41-\mathrm{J}$ transition temperature, slightly decreased the upper-shelf impact energy, and increased the 68-J transition temperature; and (2) increasing the thermal aging time from 1605 to $20,000 \mathrm{~h}$ at $288^{\circ} \mathrm{C}$ did not affect the impact properties. The effects of thermal aging on lateral expansion were small and showed a relatively larger scatter.

The effects of thermal aging at $343^{\circ} \mathrm{C}$ on the upper and lower shelves (for both impact energy and lateral expansion) were similar to those due to aging at $288^{\circ} \mathrm{C}$ for 1605 or $20,000 \mathrm{~h}$. However, the $343^{\circ} \mathrm{C}$ aging caused much greater increases in the 41 - and $68-\mathrm{J}$ transition temperatures compared to aging at $288^{\circ} \mathrm{C}$, as shown in Table 7 and Figures 8 through 11. A comparison of the effects of thermal aging on the Charpy impact energy. and lateral expansion is shown in Figures 12 and 13.

\subsubsection{Tensile Properties}

The effects of thermal aging at 288 or at $343^{\circ} \mathrm{C}$ on the yield and ultimate tensile strength were negligible (small measured increases), as can be seen from Table 8 . However, the total elongation decreased approximately 40 to $49 \%$ at $-125^{\circ} \mathrm{C}$, did not change at room temperature, and increased 19 to $37 \%$ at $288^{\circ} \mathrm{C}$. Figures 14 through 16 show a comparison of the tensile test results for the three cladding conditions (as-received, aged $20,000 \mathrm{~h}$ at $288^{\circ} \mathrm{C}$, and aged $20,000 \mathrm{~h}$ at $343^{\circ} \mathrm{C}$ ).

\subsubsection{Fracture Toughness}

The effects of thermal aging at 288 or $343^{\circ} \mathrm{C}$ for $20,000 \mathrm{~h}$ are summarized in Tables 9 and 10 and shown in Figures 17 through 20 . Thermal aging at these temperatures decreased the tearing modulus. However, the effects of thermal aging on the initiation fracture toughness, $J_{l e}$, were very small but inconsistent. The small number of specimens tested showed both higher and lower $\mathrm{J}_{\mathrm{k}}$ toughness values at the three test temperatures of 20,120, and $288^{\circ} \mathrm{C}$, indicating that thermal aging up to $20,000 \mathrm{~h}$ did not significantly degrade the initiation fracture toughness, $J_{l e}$, of this three-wire stainless steel cladding material.

\section{Conclusions and Description of Future Work}

Thermal aging of three-wire stainless steel weld overlay cladding at $288^{\circ} \mathrm{C}$ for $1605 \mathrm{~h}$ resulted in an appreciable decrease $(16 \%)$ in the CVN USE, but the effect on the $41-\mathrm{J}$ transition temperature shift was negligible $\left(3^{\circ} \mathrm{C}\right)$. The combined effect following neutron irradiation at $288^{\circ} \mathrm{C}$ to a fluence of $5 \times 10^{19}$ neutrons $/ \mathrm{cm}^{2}(>1 \mathrm{MeV}$ ) was a $22 \%$ reduction in the CVN USE and a $29^{\circ} \mathrm{C}$ shift at the $41-\mathrm{J}$ level. The effect of thermal aging on tensile properties was very small or negligible. However, the combined effect after neutron irradiation was an increase (6 to $34 \%$ at test temperatures for 288 to $-125^{\circ} \mathrm{C}$ ) in the yield strength and no apparent change in ultimate strength and total elongation. Neutron irradiation reduced the initiation fracture toughness $\left(J_{l}\right)$ much more than did thermal aging. Furthermore, irradiation slightly reduced the tearing modulus, but no reduction was caused by thermal aging alone.

The effects of short-term thermal aging on dynamic fracture toughness values will be reported separately. The effects of long-term thermal exposure $(50,000 \mathrm{~h}$ and more) will be investigated when the specimens become available. Future work will include examining cladding from decommissioned reactors (such as the German Gundremmingen Reactor) using miniature specimen techniques to compare to ORNL's three-wire cladding. 
Table 7. Charpy impact test results for stainless steel three-wire series-arc cladding (L-S orientation)

\begin{tabular}{||l|c|c|c|c|c|c|c||}
\hline \multirow{2}{*}{$\begin{array}{c}\text { Material } \\
\text { condition }\end{array}$} & \multicolumn{3}{|c|}{$\begin{array}{c}\text { Transition temperature } \\
\left({ }^{\circ} \mathrm{C}\right)\end{array}$} & \multicolumn{2}{c|}{$\begin{array}{c}\text { Energy } \\
(\mathrm{J})\end{array}$} & \multicolumn{2}{c|}{$\begin{array}{c}\text { Lateral } \\
\text { expansion } \\
(\mathrm{mm})\end{array}$} \\
\cline { 2 - 8 } & $41 \mathrm{~J}$ & $68 \mathrm{~J}$ & $0.38 \mathrm{~mm}$ & $\begin{array}{c}\text { Upper } \\
\text { shelf }\end{array}$ & $\begin{array}{c}\text { Lower } \\
\text { shelf }\end{array}$ & Upper & Lower" \\
\hline As-received & -43 & 6 & -51 & 83 & 14 & 1.146 & 0.229 \\
Aged at $288^{\circ} \mathrm{C}$ for $1605 \mathrm{~h}$ & -40 & 34 & -65 & 70 & 11 & 1.098 & 0.119 \\
Aged at $288^{\circ} \mathrm{C}$ for $20,000 \mathrm{~h}$ & -40 & 38 & -69 & 75 & 9 & 1.208 & 0.174 \\
Aged at $343^{\circ} \mathrm{C}$ for $20,000 \mathrm{~h}$ & -27 & 61 & -55 & 71 & 10 & 1.223 & 0.137 \\
\hline
\end{tabular}




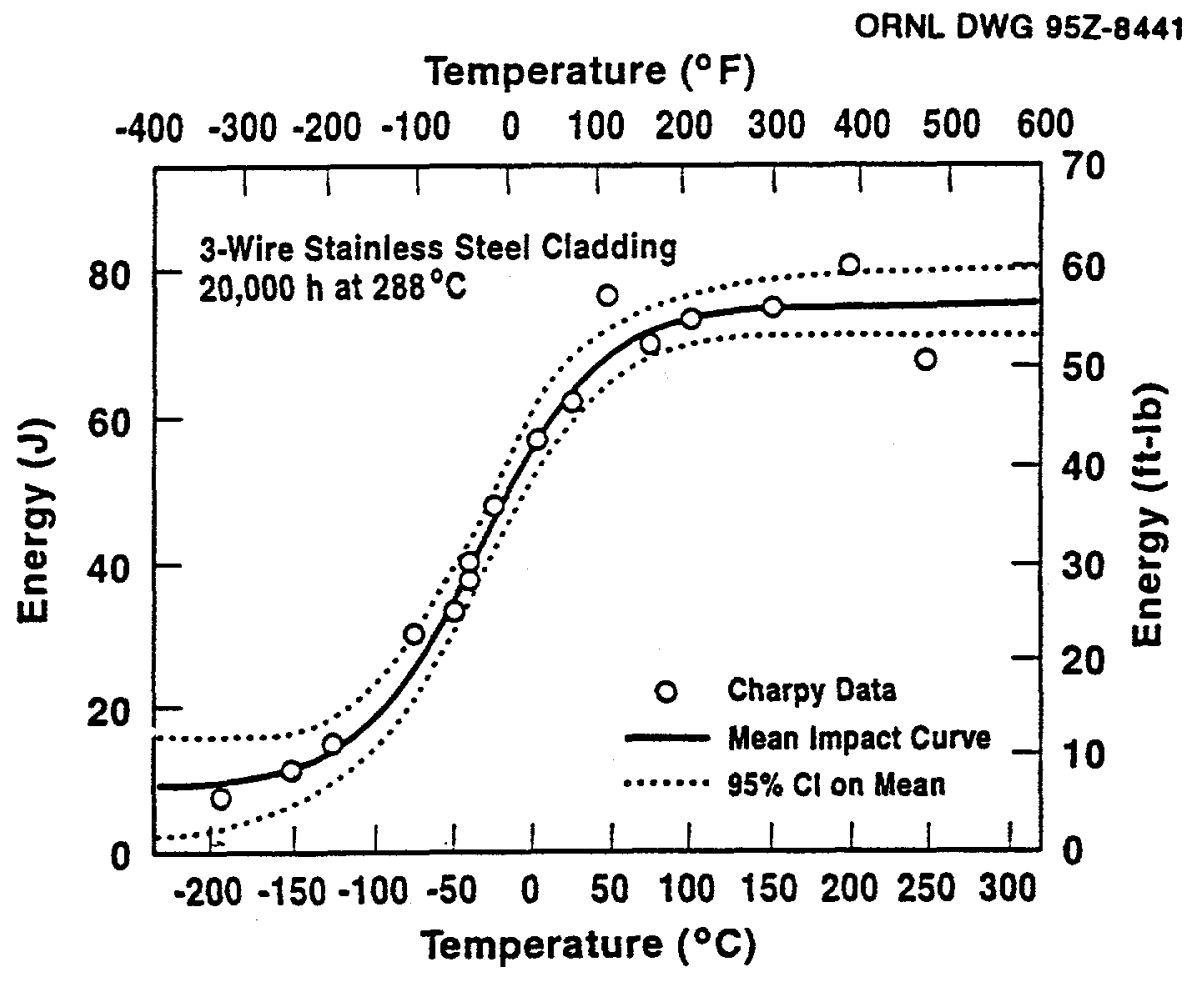

Figure. 8. Effect of thermal aging at $288^{\circ} \mathrm{C}$ for $20,000 \mathrm{~h}$ on the Charpy impact energy of three-wire series-arc stainless steel cladding, $L-S$ orientation.

Temperature $\left({ }^{\circ} \mathrm{F}\right)$

ORNL DWG $95 Z-8442$

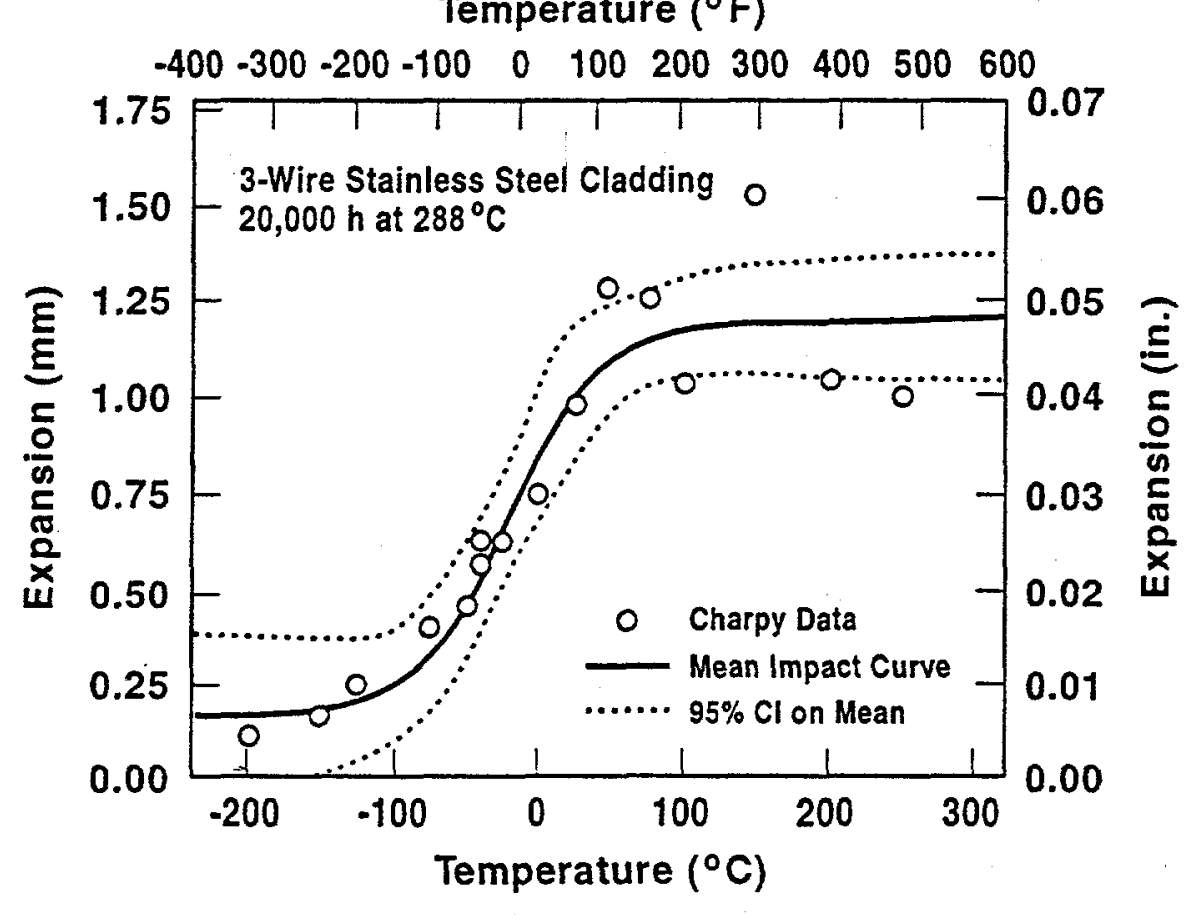

Figure 9. Effect of thermal aging at $288^{\circ} \mathrm{C}$ for $20,000 \mathrm{~h}$ on the Charpy impact lateral expansion of three-wire series-arc stainless steel cladding, L-S orientation. 


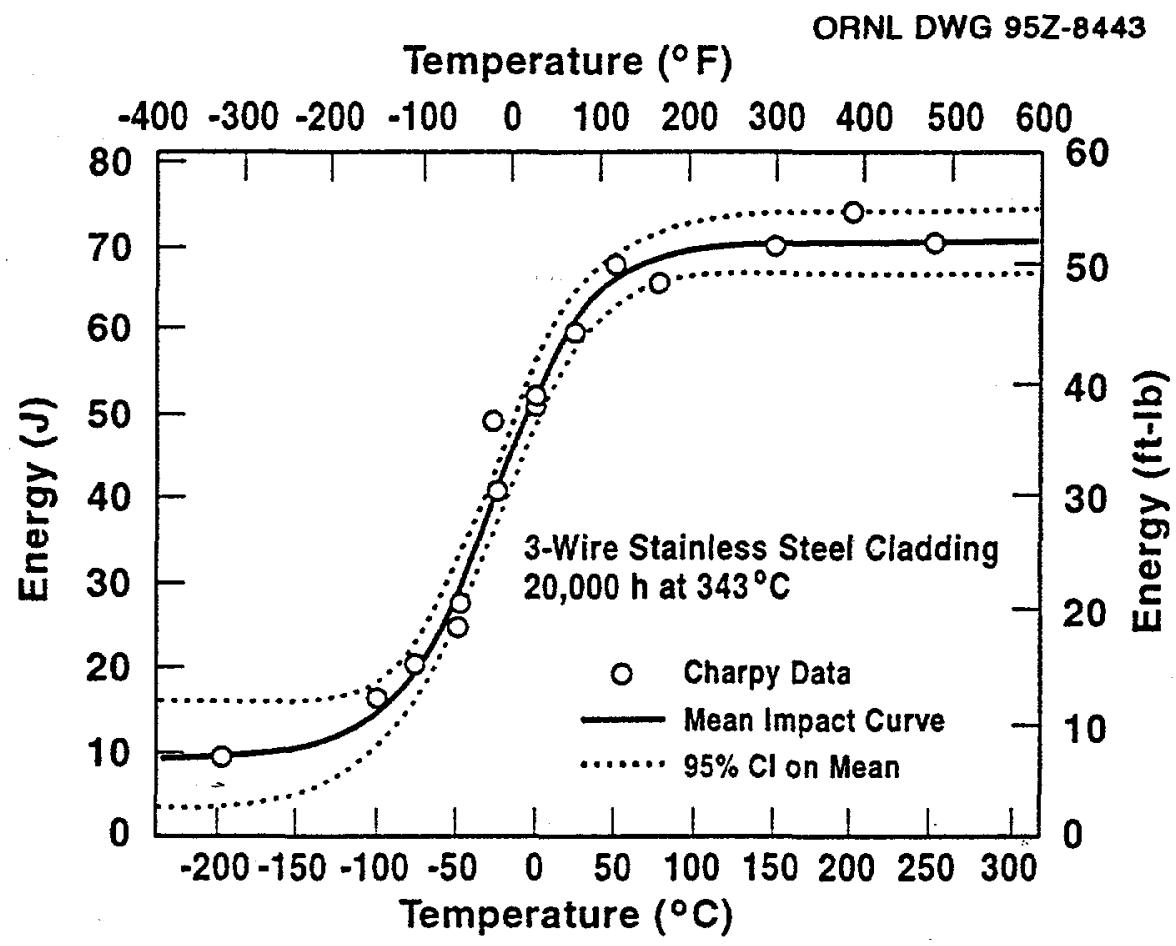

Figure 10. Effect of thermal aging at $343^{\circ} \mathrm{C}$ for $20,000 \mathrm{~h}$ on the Charpy impact energy of three-wire series-arc stainless steel cladding, LSS orientation.

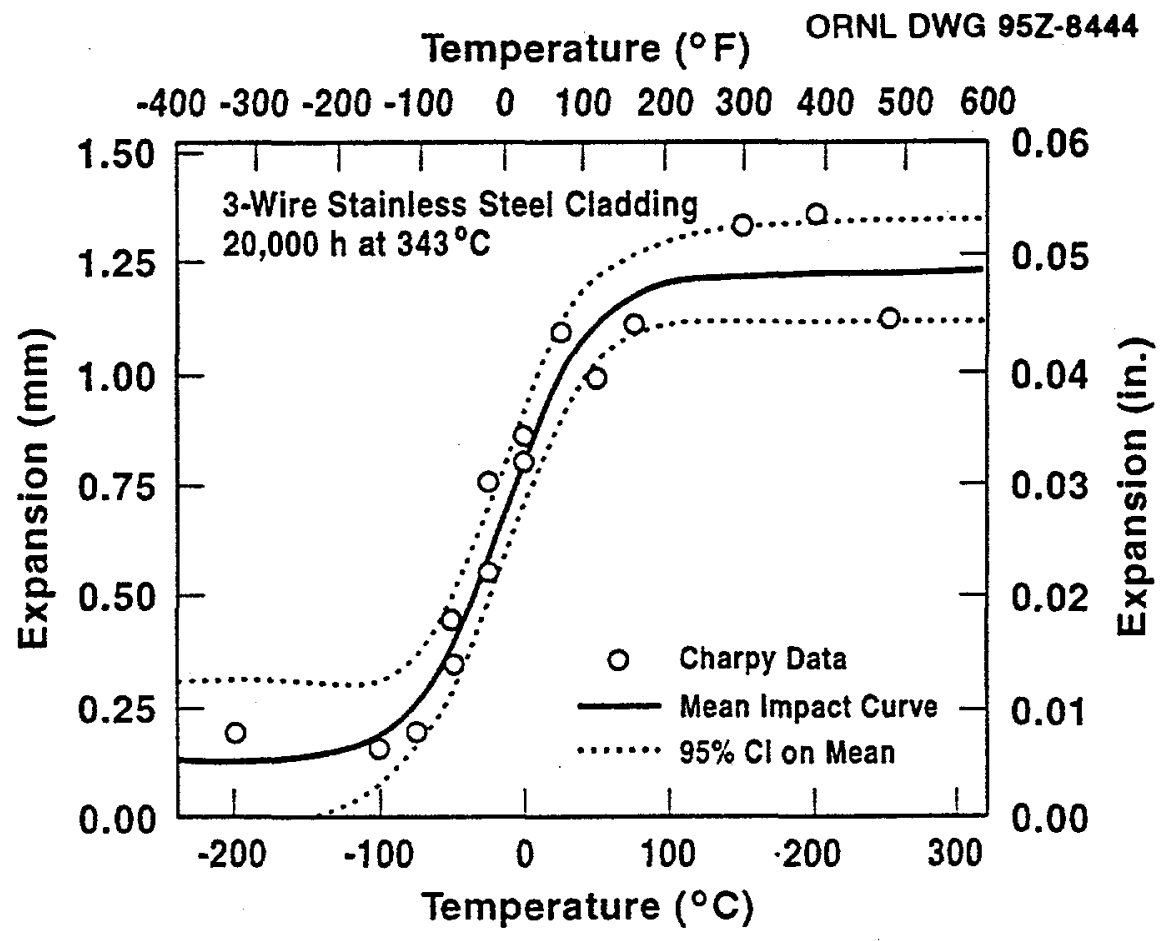

Figure 11. Effect of thermal aging at $343^{\circ} \mathrm{C}$ for $20,000 \mathrm{~h}$ on the Charpy impact lateral expansion of three-wire series-arc stainless steel cladding, L-S orientation. 


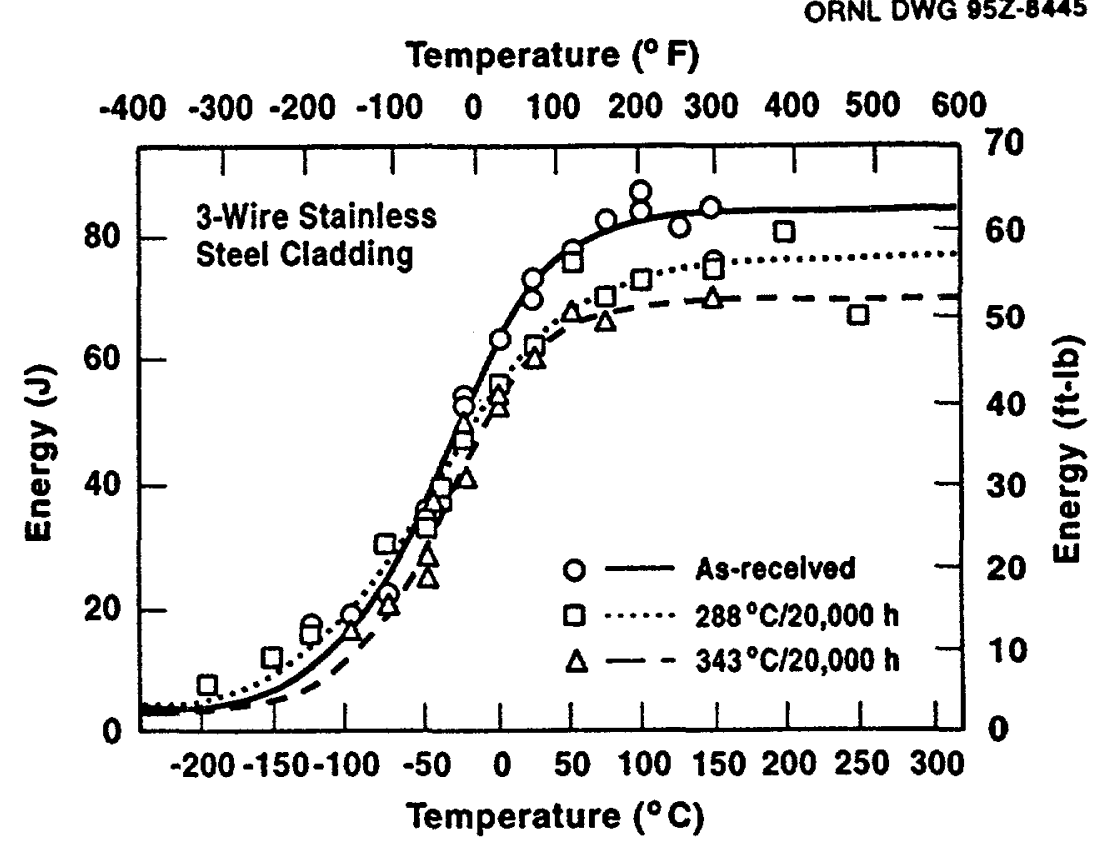

Figure 12. Comparison of the effects of thermal aging at 288 or $343^{\circ} \mathrm{C}$ for $20,000 \mathrm{~h}$ on the Charpy impact energy of three-wire series-arc stainless steel cladding, L-S orientation.

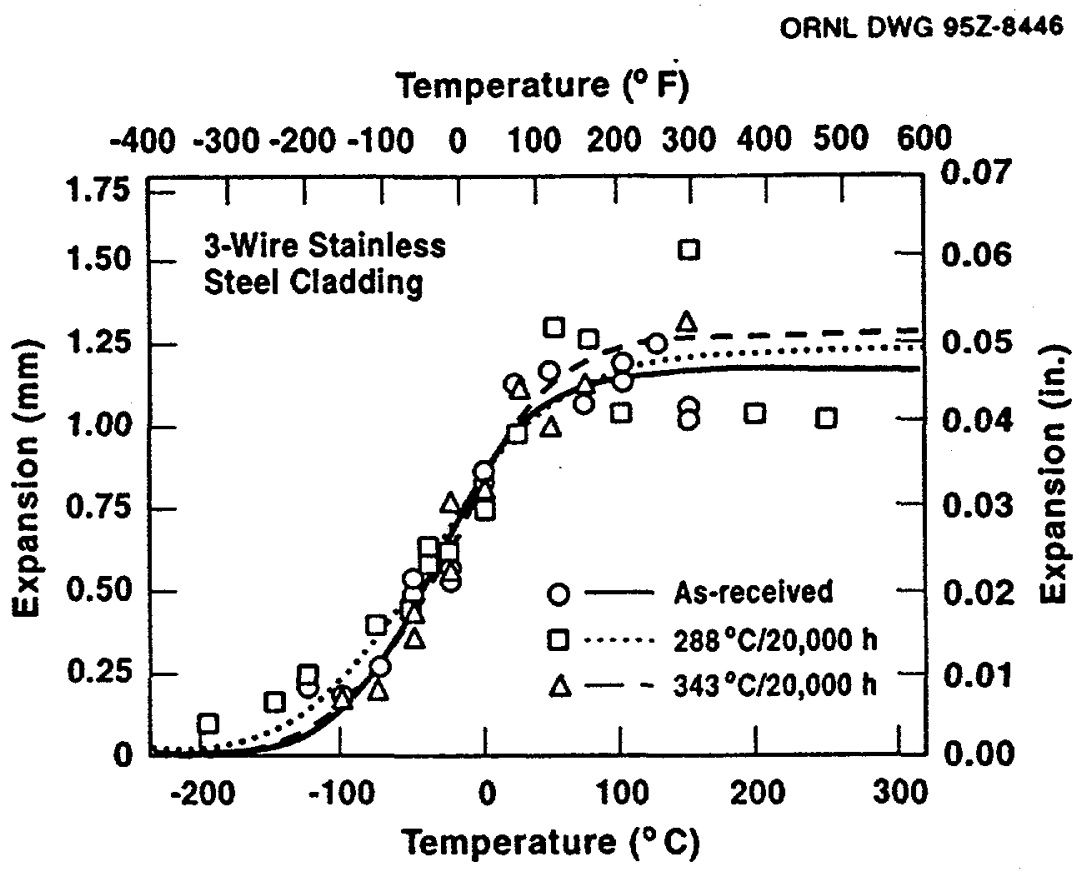

Figure 13. Comparison of the effects of thermal aging at 288 or $343^{\circ} \mathrm{C}$ for $20,000 \mathrm{~h}$ on the Charpy impact lateral expansion of three-wire series-arc stainless steel cladding, L-S orientation. 
Table 8. Tensile properties of three-wire series-arc cladding specimens in the $L$ orientation

\begin{tabular}{|c|c|c|c|c|}
\hline \multirow{2}{*}{ Specimen } & \multirow{2}{*}{$\begin{array}{c}\text { Test } \\
\text { temperature } \\
\left({ }^{\circ} \mathrm{C}\right)\end{array}$} & \multicolumn{2}{|c|}{$\begin{array}{c}\text { Tensile strength } \\
\text { (MPa) }\end{array}$} & \multirow{2}{*}{$\begin{array}{c}\text { Total } \\
\text { elongation } \\
(\%)\end{array}$} \\
\hline & & Yield & Ultimate & \\
\hline \multicolumn{5}{|c|}{ As-received } \\
\hline $\begin{array}{l}A 16 A \\
A 16 B \\
A 26 A \\
A 26 B \\
A 20 A \\
A 20 B\end{array}$ & $\begin{array}{r}-125 \\
-125 \\
21 \\
21 \\
288 \\
288\end{array}$ & $\begin{array}{l}357 \\
338 \\
301 \\
297 \\
218 \\
252\end{array}$ & $\begin{array}{r}1169 \\
1150 \\
574 \\
577 \\
409 \\
402\end{array}$ & $\begin{array}{l}39 \\
39 \\
47 \\
47 \\
23 \\
20\end{array}$ \\
\hline \multicolumn{5}{|c|}{ Aged at $288^{\circ} \mathrm{C}$ for $20,000 \mathrm{~h}$} \\
\hline $\begin{array}{l}\text { BAT02 } \\
\text { BAT05 }^{\circ} \\
\text { BAT01 } \\
\text { BAT04 } \\
\text { BAT03 } \\
\text { BAT06 }\end{array}$ & $\begin{array}{r}-127 \\
-127 \\
21 \\
21 \\
288 \\
288\end{array}$ & $\begin{array}{l}386 \\
\\
309 \\
315 \\
230 \\
232\end{array}$ & $\begin{array}{l}1215 \\
579 \\
562 \\
396 \\
391\end{array}$ & $\begin{array}{l}23 \\
\\
47 \\
49 \\
32 \\
27\end{array}$ \\
\hline \multicolumn{5}{|c|}{ Aged at $343^{\circ} \mathrm{C}$ for $20,000 \mathrm{~h}$} \\
\hline $\begin{array}{l}\text { T302 } \\
\text { T305 } \\
\text { T301 } \\
\text { T304 } \\
\text { T303 } \\
\text { T306 }\end{array}$ & $\begin{array}{r}-127 \\
-127 \\
25 \\
25 \\
288 \\
288\end{array}$ & $\begin{array}{l}399 \\
315 \\
322 \\
240 \\
241\end{array}$ & $\begin{array}{l}1073 \\
576 \\
576 \\
409 \\
430\end{array}$ & $\begin{array}{l}20 \\
47 \\
48 \\
29 \\
23\end{array}$ \\
\hline
\end{tabular}




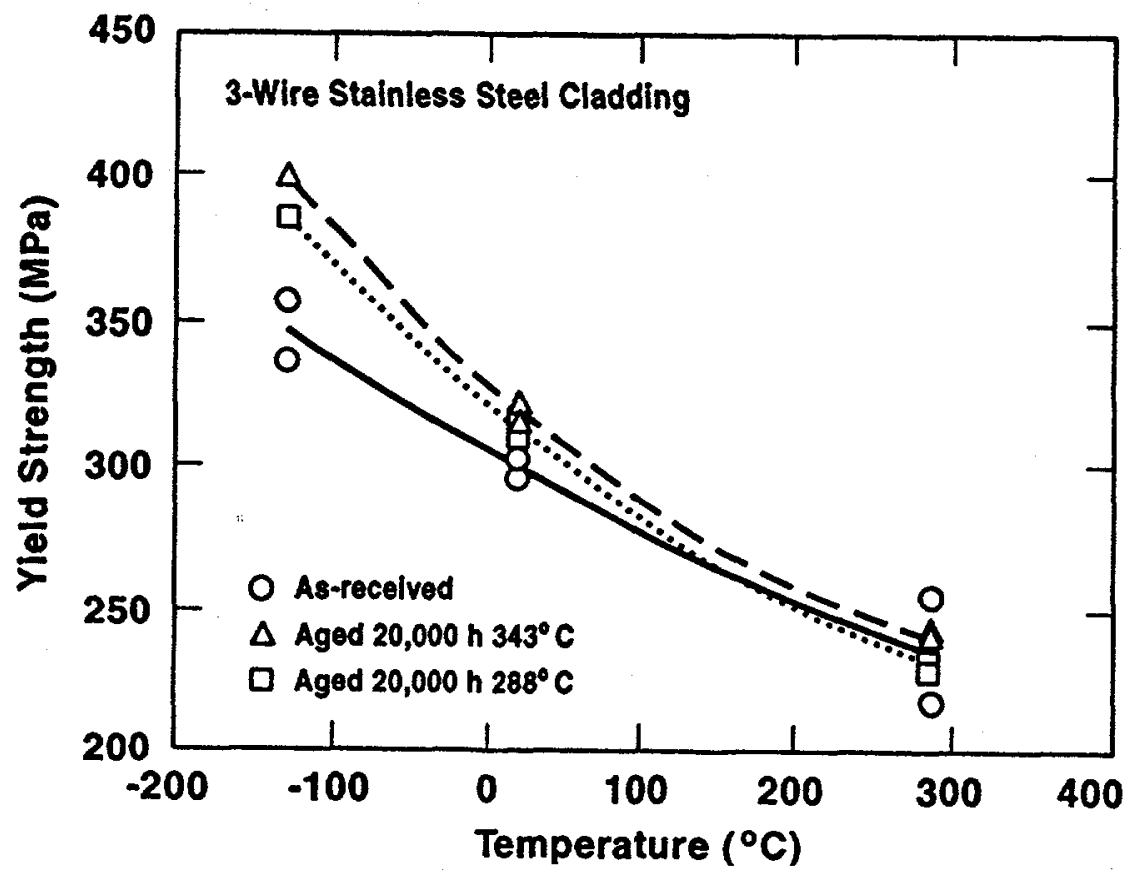

Figure 14. Comparison of the effects of thermal aging at 288 or $343^{\circ} \mathrm{C}$ for $20,000 \mathrm{~h}$ on the yield strength of three-wire series-arc stainless steel cladding.

ORNL DWG 952-8448

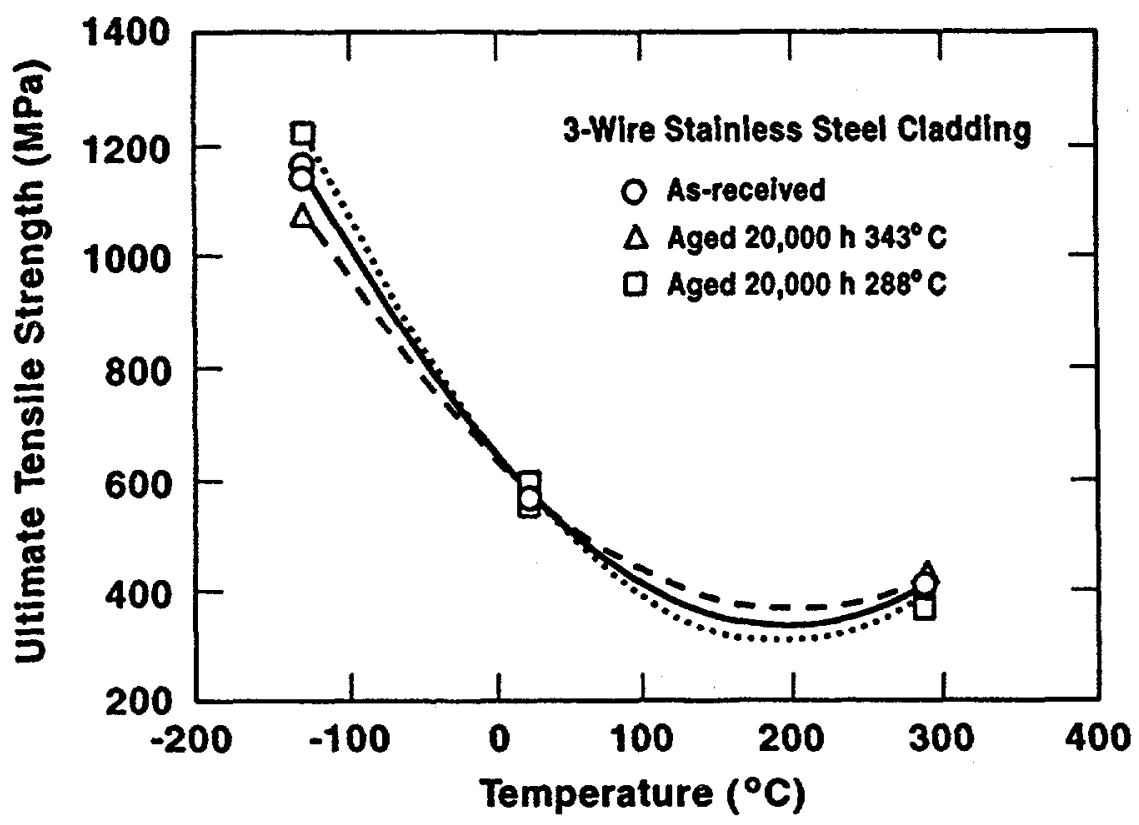

Figure 15. Comparison of the effects of thermal aging at 288 or $343^{\circ} \mathrm{C}$ for $20,000 \mathrm{~h}$ on the ultimate strength of three-wire series-arc stainless steel cladding. 
ORNL DWG 95Z-8449

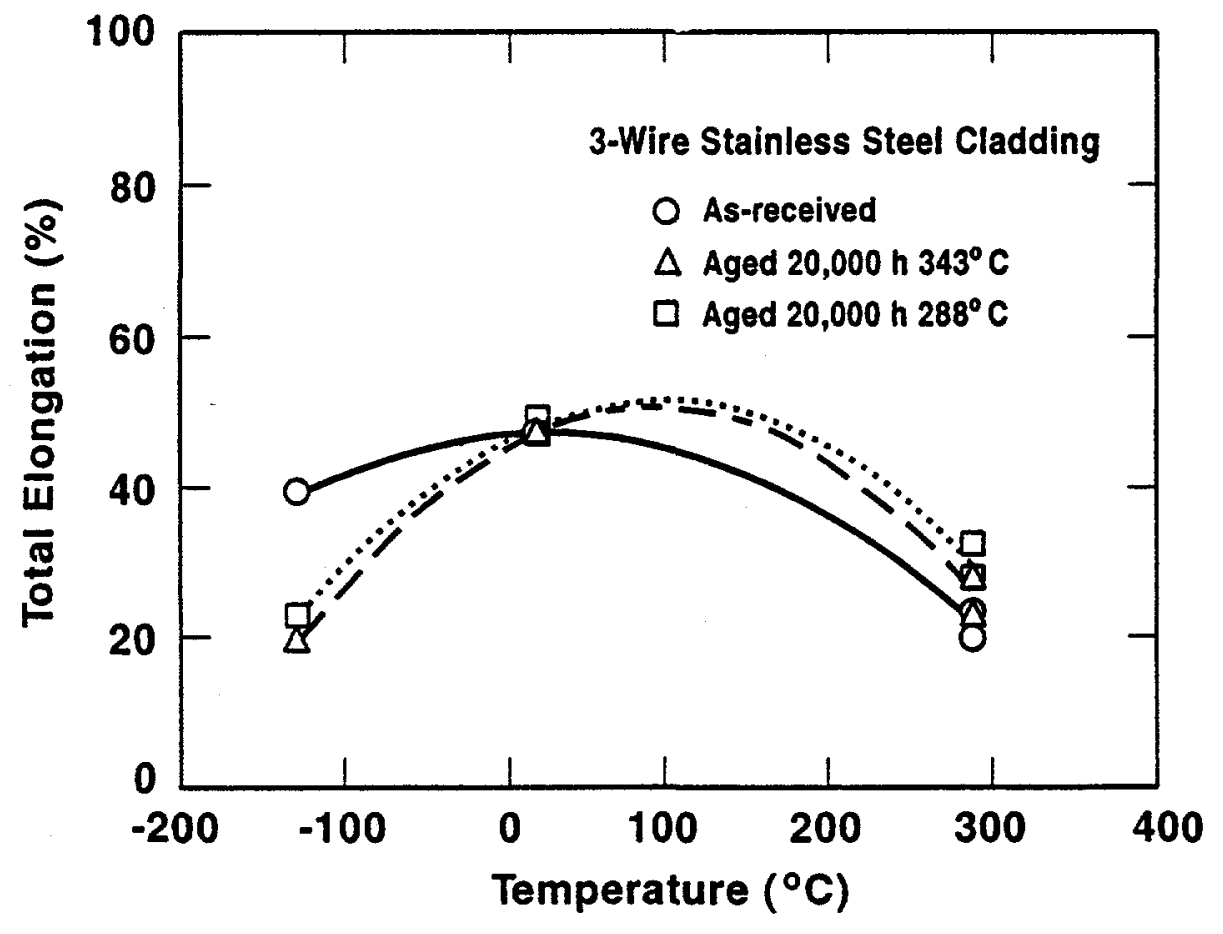

Figure 16. Comparison of the effects of thermal aging at 288 or $343^{\circ} \mathrm{C}$ for $20,000 \mathrm{~h}$ on the total elongation of three-wire series-arc stainless steel cladding. 


\begin{tabular}{|c|c|c|c|c|c|c|}
\hline \multirow{3}{*}{ 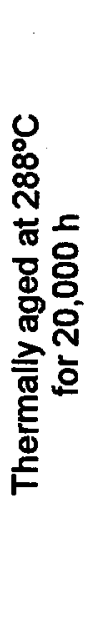 } & 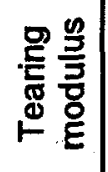 & \multicolumn{4}{|c|}{ 㞼导 喿吉 } & \multirow{2}{*}{$\frac{2 \pi}{52}$} \\
\hline & $\stackrel{\circ}{\circ \frac{\sigma}{\xi}}$ & & 吕 & $+\frac{2}{2}$ & & \\
\hline & 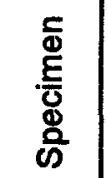 & & 遂食 & $\frac{9}{4} \frac{\bar{\alpha}}{\alpha}$ & & $\sum^{\frac{m}{2}}$ \\
\hline \multirow{3}{*}{ 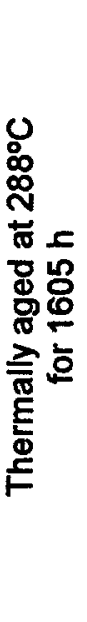 } & 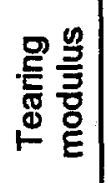 & & $\stackrel{\varpi}{\longleftarrow}$ & $\stackrel{\infty}{\sim} \stackrel{\sim}{\sim ్}$ & & º \\
\hline & $\sim \frac{\sigma}{\underline{\underline{\xi}}}$ & & 军 & 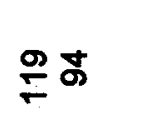 & & ๓ヌロ \\
\hline & 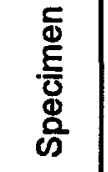 & & 소오 & 오웅 & & 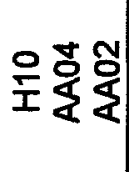 \\
\hline \multirow{3}{*}{ 浐 } & 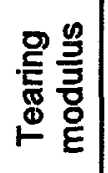 & & 용 & กึูลิ & สิส & $\stackrel{N}{N}=\stackrel{\infty}{=}$ \\
\hline & 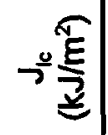 & 윰 & 뜸용 & 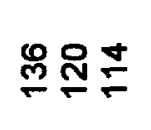 & 용 & RR \\
\hline & 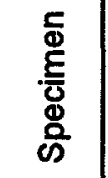 & 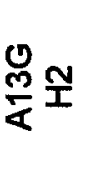 & $\frac{0}{4} \frac{0}{4}$ & 뿡오오 & 오포 & 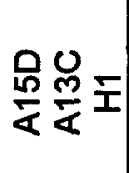 \\
\hline 岕 & $\frac{\sigma}{0}$ & 色 & กิกิ & ํㅗำำ & 윰ำ & 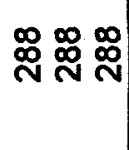 \\
\hline
\end{tabular}


Table 10. Unloading compliance J-R test results of as-received and thermally aged $12.7-\mathrm{mm}$-thick three-wire stainless steel cladding fracture toughness specimens ( $10 \%$ side-grooved on each side)

\begin{tabular}{|c|c|c|c|c|c|c|c|c|c|}
\hline \multirow{2}{*}{$\begin{array}{c}\text { Test } \\
\text { temperature } \\
\left({ }^{\circ} \mathrm{C}\right)\end{array}$} & \multicolumn{3}{|c|}{ As-received } & \multicolumn{3}{|c|}{$\begin{array}{c}\text { Thermally aged at } 288{ }^{\circ} \mathrm{C} \\
\text { for } 20,000 \mathrm{~h}\end{array}$} & \multicolumn{3}{|c|}{$\begin{array}{c}\text { Thermally aged at } 343^{\circ} \mathrm{C} \\
\text { for } 20,000 \mathrm{~h}\end{array}$} \\
\hline & Specimen & $\begin{array}{c}J_{\mathrm{le}} \\
\left(\mathrm{kJ} / \mathrm{m}^{2}\right)\end{array}$ & $\begin{array}{l}\text { Tearing } \\
\text { modulus }\end{array}$ & Specimen & $\begin{array}{c}J_{1 c} \\
\left(k J / m^{2}\right)\end{array}$ & $\begin{array}{l}\text { Tearing } \\
\text { modulus }\end{array}$ & Specimen & $\begin{array}{c}J_{1 c} \\
\left(k J / m^{2}\right)\end{array}$ & $\begin{array}{l}\text { Tearing } \\
\text { modulus }\end{array}$ \\
\hline $\begin{array}{l}-75 \\
-75\end{array}$ & $\begin{array}{l}A 13 G \\
H 2\end{array}$ & $\begin{array}{l}116 \\
145\end{array}$ & $\begin{array}{l}62 \\
35\end{array}$ & & & & & & \\
\hline $\begin{array}{l}20 \\
20\end{array}$ & $\begin{array}{l}\text { A13D } \\
\text { A10G }\end{array}$ & $\begin{array}{l}132 \\
169\end{array}$ & $\begin{array}{l}203 \\
159\end{array}$ & $\begin{array}{l}\text { AA05 } \\
\text { AA07 }\end{array}$ & $\begin{array}{l}159 \\
153\end{array}$ & $\begin{array}{l}143 \\
149\end{array}$ & $\begin{array}{l}\mathrm{H} 11 \\
\mathrm{H} 12\end{array}$ & $\begin{array}{l}152 \\
112\end{array}$ & $\begin{array}{l}134 \\
119\end{array}$ \\
\hline $\begin{array}{l}120 \\
120 \\
120\end{array}$ & $\begin{array}{l}\text { A10E } \\
\text { H5 } \\
\text { H3 }\end{array}$ & $\begin{array}{l}136 \\
120 \\
114\end{array}$ & $\begin{array}{l}233 \\
207 \\
214\end{array}$ & $\begin{array}{l}\text { AA09 } \\
\text { AA11 }\end{array}$ & $\begin{array}{l}147 \\
175\end{array}$ & $\begin{array}{l}198 \\
174\end{array}$ & $\begin{array}{l}\mathrm{H} 13 \\
\mathrm{H} 14\end{array}$ & $\begin{array}{l}135 \\
134\end{array}$ & $\begin{array}{l}175 \\
156\end{array}$ \\
\hline $\begin{array}{l}200 \\
200\end{array}$ & $\begin{array}{l}\mathrm{H} 6 \\
\mathrm{H} 4\end{array}$ & $\begin{array}{r}95 \\
100\end{array}$ & $\begin{array}{l}220 \\
221\end{array}$ & & & & & & \\
\hline $\begin{array}{l}288 \\
288 \\
288\end{array}$ & $\begin{array}{c}A 15 D \\
A 13 C \\
H 1\end{array}$ & $\begin{array}{l}76 \\
70 \\
83 \\
\end{array}$ & $\begin{array}{l}278 \\
171 \\
185 \\
\end{array}$ & $\begin{array}{l}\text { AA13 } \\
\text { AA15 }\end{array}$ & $\begin{array}{l}91 \\
77\end{array}$ & $\begin{array}{l}173 \\
142\end{array}$ & $\begin{array}{l}\mathrm{H} 15 \\
\mathrm{H} 16\end{array}$ & $\begin{array}{l}111 \\
110\end{array}$ & $\begin{array}{l}147 \\
153\end{array}$ \\
\hline
\end{tabular}


ORNL DWG 95Z-8450

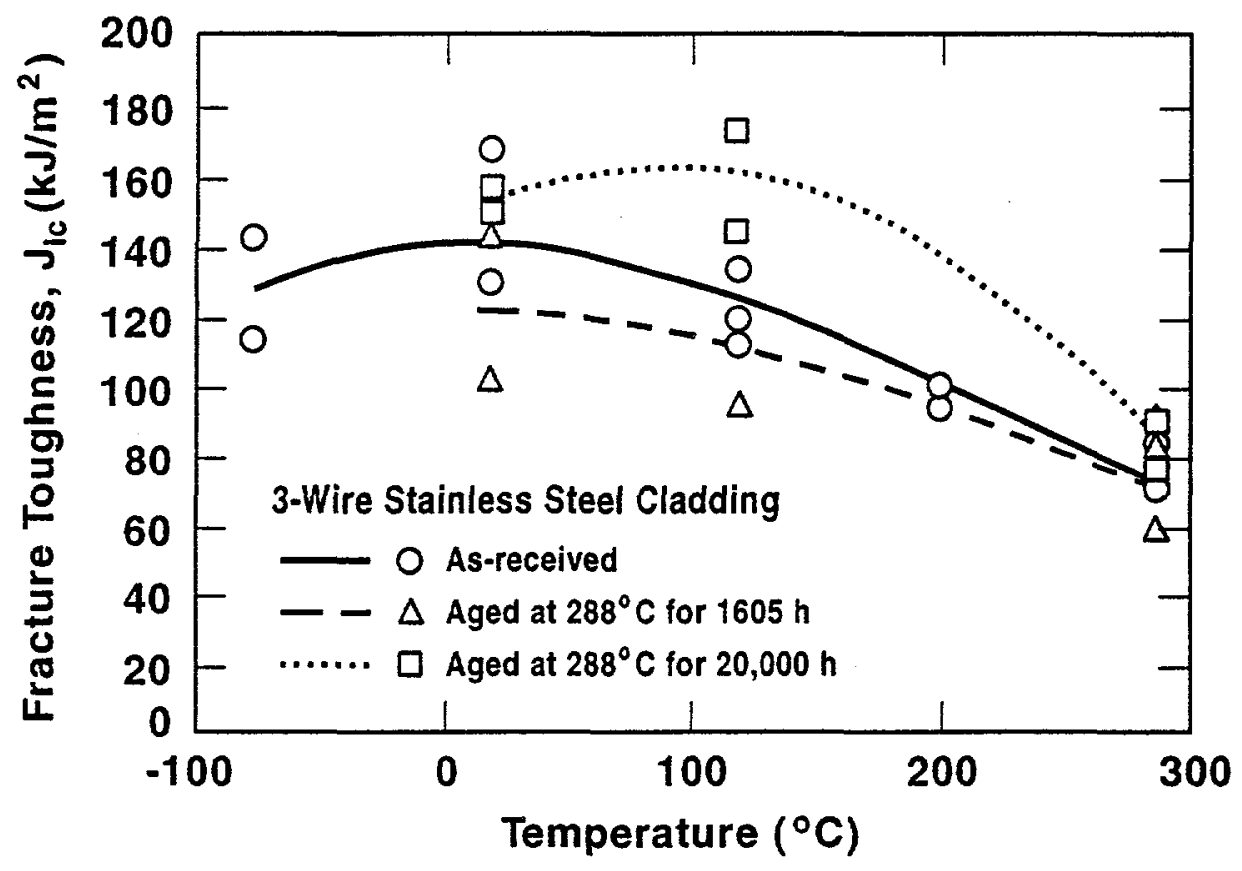

Figure 17. Effect of thermal aging at $288^{\circ} \mathrm{C}$ for 1605 or $20,000 \mathrm{~h}$ on the initiation fracture toughness $\left(\mathrm{J}_{\mathrm{le}}\right)$ of three-wire series-arc stainless steel cladding.

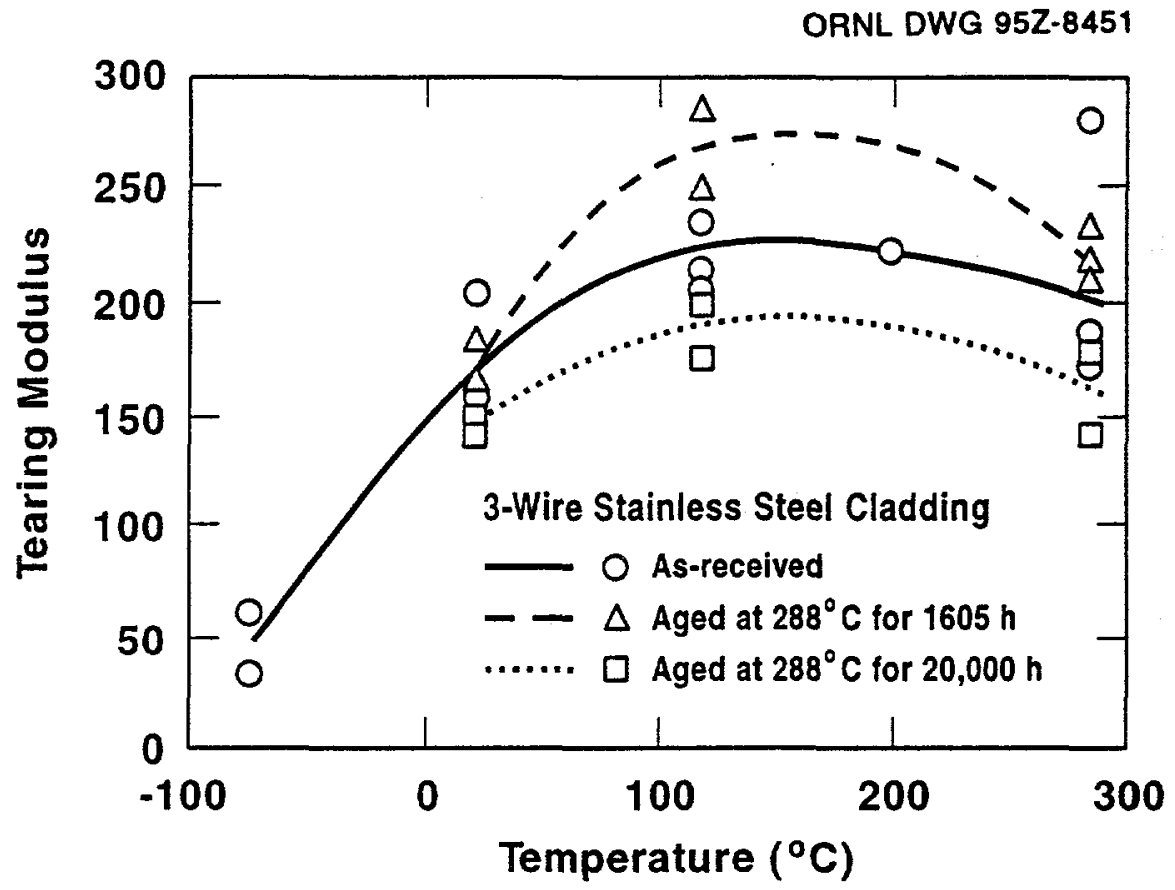

Figure 18. Effect of thermal aging at $288^{\circ} \mathrm{C}$ for 1605 or $20,000 \mathrm{~h}$ on the tearing modulus of three-wire series-arc stainless steel cladding. 


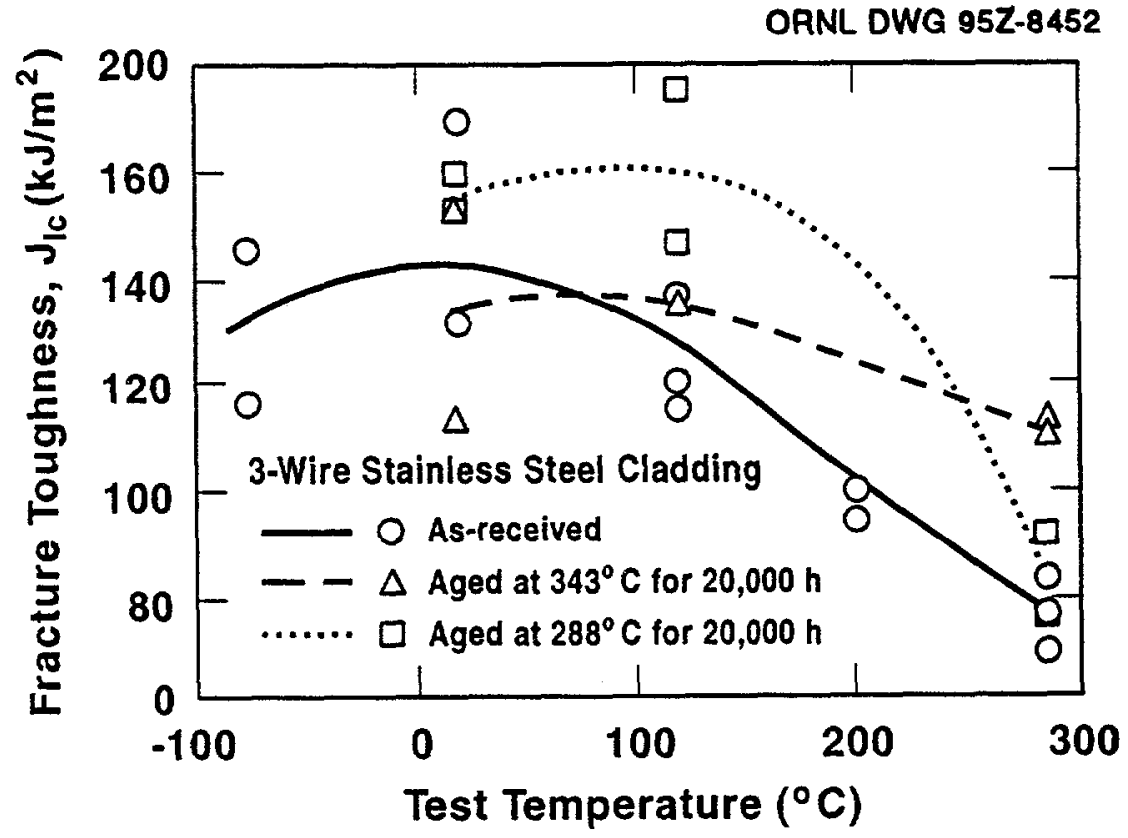

Figure 19. Comparison of the effects of thermal aging at 288 or $343^{\circ} \mathrm{C}$ for $20,000 \mathrm{~h}$ on the initiation fracture toughness $\left(\mathrm{J}_{\mathrm{te}}\right)$ of three-wire series-arc stainless steel cladding.

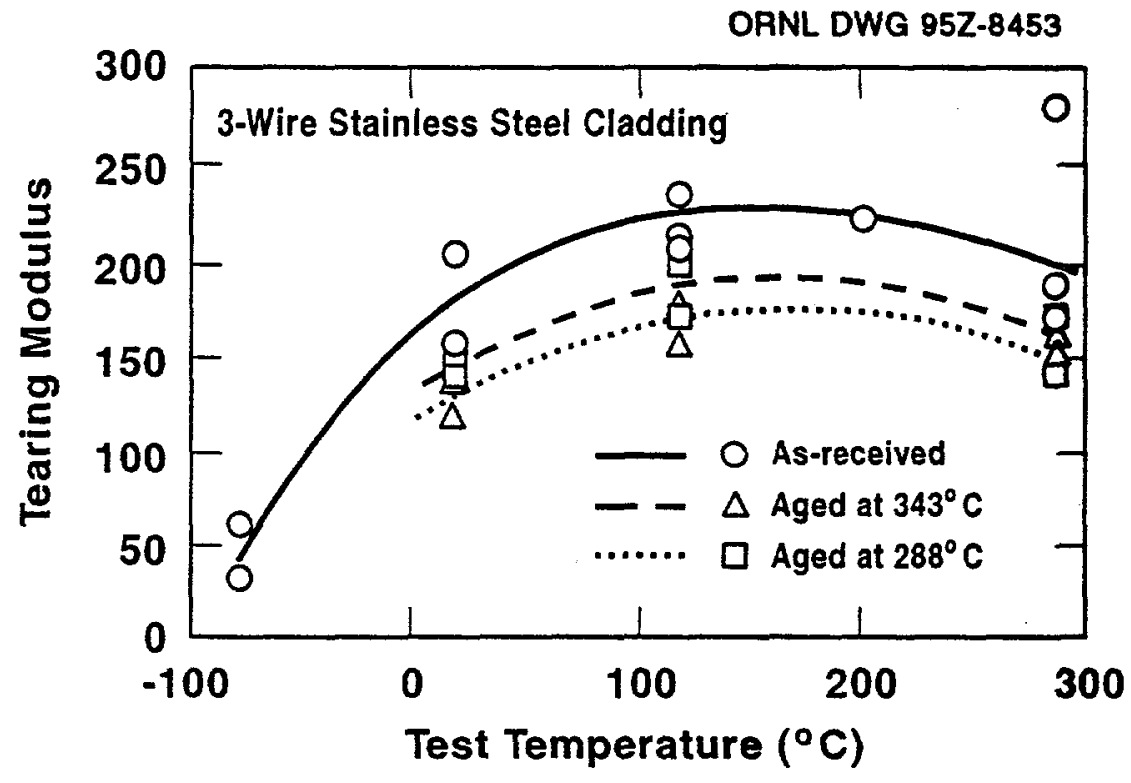

Figure 20. Comparison of the effects of thermal aging at 288 or $343^{\circ} \mathrm{C}$ for $20,000 \mathrm{~h}$ on the tearing modulus of three-wire series-arc stainless steel cladding. 


\section{References}

1. D. J. Alexander, K. B. Alexander, and R. K. Nanstad, "The Effect of Aging at $343^{\circ} \mathrm{C}$ on Type 308 Stainless Steel Welds," pp. 217-21 in Recent Trends in Welding Science and Technology, Proceedings of the 2nd International Conference on Trends in Welding Research, Gatlinburg, Tennessee, May 14-18, 1989, Ed. S. A. David and J. M. Vitek, ASM International, Materials Park, Ohio, 1990."

2. F. M. Haggag, W. R. Corwin, D. J. Alexander, and R. K. Nanstad, Martin Marietta Energy Systems, Inc., Oak Ridge Natl. Lab., Oak Ridge, Tenn., "Effects of Irradiation on Strength and Toughness of Commercial LWR Vessel Cladding," pp. 177-93 in Proceedings of the U.S. Nuclear Regulatory Commission Fiffeenth Water Reactor Safety Information Meeting, Gaithersburg, Maryland, October 26-29, 1987, USNRC Conference Proceedings NUREG/CP-0091, Vol. 2, February 1988. ${ }^{\dagger}$

3. F. M. Haggag and S. K. Iskander, Martin Marietta Energy Systems, Inc., Oak Ridge Natl. Lab., Oak Ridge, Tenn., "Results of Irradiated Cladding Tests and Clad Plate Experiments," pp. 355-69 in Proceedings of the U.S. Nuclear Regulatory Commission Sixteenth Water Reactor Safety Information Meeting, Gaithersburg, Maryland, October 24-27, 1988, USNRC Conference Proceedings NUREG/CP0097, Vol. 2, March 1989. ${ }^{\dagger}$

4. F. M. Haggag, W. R. Corwin, D. J. Alexander, and R. K. Nanstad, "Tensile and Charpy Impact Behavior of an Irradiated Three-Wire Series-Arc Stainless Steel Cladding," pp. 361-72 in Effects of Radiation on Materials: 14th International Symposium (Volume II), ASTM STP 1046, Ed. N. H. Packan, R. E. Stoller, and A. S. Kumar, American Society for Testing and Materials, Philadelphia, 1990.*

5. F. M. Haggag, W. R. Corwin, and R. K. Nanstad, Martin Marietta Energy Systems, Inc., Oak Ridge Natl. Lab., Oak Ridge, Tenn., Irradiation Effects on Strength and Toughness of Three-Wire Series-Arc Stainless Steel Weld Overlay Cladding, USNRC Report NUREG/CR-5511 (ORNL/TM-11439), February 1990. ${ }^{\dagger}$

6. W. R. Corwin, R. G. Berggren, R. K. Nanstad, and R. J. Gray, "Fracture Behavior of a Neutron-Irradiated Stainless Steel Submerged Arc Weld Cladding Overlay," Nucl. Eng. Des. 89, 199-221 (1985).*

7. F. M. Haggag, W. R. Corwin, and R. K. Nanstad, "Effects of Irradiation on the Fracture Properties of Stainless Steel Weld Overlay Cladding," Nucl. Eng. Des. 124, 129-41 (1990)."

8. E. A. Wimunc, "How Serious are Cladding Failures?" Power Reactor Technol. 9(3), 101-9 (1966)."

9. J. Keeney-Walker, B. R. Bass, and W. E. Pennell, "Evaluation of the Effects of Irradiated Cladding on the Behavior of Shallow Flaws Subjected to Pressurized-Thermal-Shock Loading," pp. 195-200 in Transactions of the 11th International Conference on Structural Mechanics in Reactor Technology (SMiRT 11), Vol. G (August 1991).*

\footnotetext{
"Available in public technical libraries.

${ }^{\dagger}$ Available for purchase from National Technical Information Service, Springfield, VA, 22161.
} 


\begin{tabular}{|c|c|}
\hline $\begin{array}{l}\text { U.S. MUCLEAR REGULATOAY COMMISSION } \\
\text { BIBLIOGRAPHIC DATA SHEET } \\
\text { (Sec instructions on the reverse) }\end{array}$ & 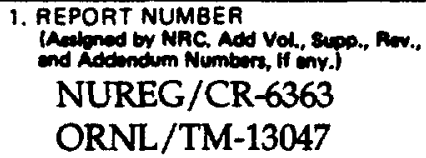 \\
\hline \multicolumn{2}{|l|}{ 2. TITLE AND SUBTITLE } \\
\hline \multirow{3}{*}{$\begin{array}{l}\text { Effects of Thermal Aging and Neutron Irradiation on the Mechanical Properties of } \\
\text { Three-Wire Stainless Steel Weld Overlay Cladding }\end{array}$} & DATE REPORT PUBLISHED \\
\hline & \begin{tabular}{l|l} 
MONTH & YEAA \\
May & 1997 \\
\end{tabular} \\
\hline & $\begin{array}{l}\text { 4. FIN OA GRANT NUMBER } \\
\text { L1098 }\end{array}$ \\
\hline 5. AUTHOR(S) & 6. TYPE OF REPORT \\
\hline \multirow{2}{*}{ F. M. Haggag and R. K. Nanstad } & Technical \\
\hline & 7. PERIOD COVERED (inclusive Dates) \\
\hline
\end{tabular}

neme asd mailing addmen!

Oak Ridge National Laboratory

Oak Ridge, TN 37831-6285

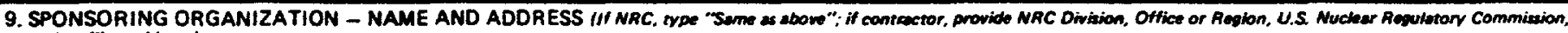
ind mailing edoress)

Division of Engineering Technology

Office of Nuclear Regulatory Research

U.S. Nuclear Regulatory Commission

Washington. DC 20555-0001

10. SUPPLEMENTARY NOTES

M. Vassilaros, NRC Project Manager

11. ABSTRACT (200 wand or wese)

Thermal aging of three-wire series-arc stainless steel weld overlay cladding at $288^{\circ} \mathrm{C}$ for $1605 \mathrm{~h}$ resulted in an appreciable decrease (16\%) in the Charpy V-notch (CVN) upper-shelf energy (USE), but the effect on the $41 \mathrm{~J}$ transition temperature shift was very small $\left(3^{\circ} \mathrm{C}\right)$. The combined effect of aging and neutron irradiation at $288^{\circ} \mathrm{C}$ to a fluence of $5 \times 10^{10}$ neutrons $/ \mathrm{cm}^{2}(>1 \mathrm{MeV})$ was a $22 \%$ reduction in the USE and a $29^{\circ} \mathrm{C}$ shift in the $41 \mathrm{~J}$ transition temperature. The effect of thermal aging on tensile properties was very small. However, the combined effect of imradiation and aging was an increase in the yield strength ( 6 to $34 \%$ at test temperatures from 288 to $-125^{\circ} \mathrm{C}$ ) but no apparent change in ultimate tensile strength or total elongation. Neutron irradiation reduced the initiation fracture toughness $\left(J_{k}\right)$ much more than did thermal aging alone. Irradiation slightly decreased the tearing modulus, but no reduction was caused by thermal aging alone. Other results from tensile, CVN, and fracture toughness specimens showed that the effects of thermal aging at 288 or $343^{\circ} \mathrm{C}$ for $20,000 \mathrm{~h}$ each were very small and similar to those at $288^{\circ} \mathrm{C}$ for $1605 \mathrm{~h}$. The effects of long-term thermal exposure time $\left(50,000 \mathrm{~h}\right.$ and greater) at $288^{\circ} \mathrm{C}$ will be investigated as the specimens become available in 1996 and beyond.

12. KEY WORDS/DESCR!PTORS /List worts or phrases that wilf essist researchers in locating the report.

thermal aging

stainless steel

weld overlay

cladding

fracture toughness

tensile strength

irradiation effects

\begin{tabular}{l} 
13. AVAILABILITY STATEMENT \\
Unl imited \\
\hline 14. SECURITY CLASSIFICATION \\
\hline This PSgEl \\
Inclassified \\
ithis Roport \\
Unclassified \\
15. NUMBER OF PAGES \\
\hline 16. PRICE
\end{tabular}

